\section{Mutation Breeding in Ornamentals}

\author{
Killian Melsen and Mark van de Wouw \\ HAS University of Applied Sciences, 's-Hertogenbosch, The Netherlands
}

Ryan Contreras

\section{Agricultural and Life Sciences Building, Department of Horticulture, Oregon State University, Corvallis, OR}

Additional index words. chemical mutagen, ethyl methanesulftonate, gamma radiation, physical mutagen, X-ray

\begin{abstract}
The promising possibilities of mutation breeding in ornamental plants have led to a great interest in effective mutagenic treatment protocols for various species. This review discusses mutagenic treatments of a large number of ornamental genera, the advantages and disadvantages of various techniques, and the possibilities of improving the associated protocols. A number of nontargeted mutagenesis methods are available, ranging from chemical treatment with alkylating agents to irradiation with $X$-rays, gamma rays, and neutron or heavy ion beams at various doses. These are all relatively inexpensive and have been proven to be effective mutagens in a large number of diverse species. Genetic engineering, however, remains mostly impractical for many ornamental breeding operations because of the high cost and lack of knowledge necessary to successfully transform and regenerate ornamental crops. Of the available nontargeted mutagens, irradiation with gamma rays is still the most popular. It provides high consistency compared with chemical mutagens, albeit at a seemingly lower mutagenic efficiency. Changes in the radiation dose rate may increase the efficiency, although chronic irradiation over a longer period causes fewer deleterious mutations than the commonly used acute irradiation protocols. Heavy ion beam irradiation may also provide highly consistent mutation induction at higher efficiencies because of the high particle energy associated with these treatments. There are also opportunities to improve chemical mutagenesis. Although the required knowledge of specific gene functions in many ornamentals is still lacking, combination mutagenesis with ethyl methanesulfontate with genetic screening in a process known as TILLING (Targeting Induced Local Lesions IN Genomes) may lead to a powerful mutation breeding tool in the future. Mutation breeding is still very useful, and many opportunities are available to improve the existing methods.
\end{abstract}

Naturally occurring changes in the DNA of organisms have been a primary source of genetic diversity that, through the processes of natural selection and genetic drift, have led to the evolution and abundance of different plant species that we know today (Huxley, 1942). These changes, called mutations, have also resulted in variations within many plant species. Mutations have been the source of improvements in many ornamental species such as japanese morning glory (Ipomaea nil; Miyake and Imai, 1926) and petunia (Petunia $\times$ hybrida; Sink, 1973), which is the focus of this review. However, agronomic crops have benefitted from natural variation, with the IR8 "miracle rice" variety as one of the greatest examples (Chandler, 1992; Hargrove and Cabanilla, 1979; International Rice Research

Received for publication 14 May 2021. Accepted for publication 23 July 2021.

Published online 10 September 2021.

We gratefully acknowledge Dr. Shawn Mehlenbacher and Dr. Kelly Vining for helpful input that improved the manuscript.

R.C. is the corresponding author. E-mail: ryan. contreras@oregonstate.edu.

This is an open access article distributed under the CC BY-NC-ND license (https://creativecommons. org/licenses/by-nc-nd/4.0/).
Institute, 1967; Li et al., 2020; Peng et al., 2010; Spielmeyer et al., 2002).

Numerous other examples illustrate that naturally occurring mutations have been an important source of genetic diversity and novel phenotypes for both ornamental and agronomic crops. The rate at which these mutations occur is quite low for most plants, however. Estimates range from $5.0 \times 10^{-9}$ to $3.0 \times 10^{-8}$ per site per year (Ossowski et al., 2010; Schultz et al., 1999; Wolfe et al., 1987). This low natural mutation rate and the fact that only a small portion of mutations is assumed to be observable, let alone beneficial, indicate that the chances of identifying a spontaneous mutant with a valuable, novel phenotype are very low (Elena et al., 1996; Peck, 1994; Schultz and Lynch, 1997; Sniegowski and Gerrish, 2010). Alternatively, plant material can be treated with mutagens. These treatments increase the random mutation rate, resulting in the faster accumulation of useful mutations at relatively low costs for breeding programs (Van Harten, 1998).

Such treatments were first discovered by Muller in 1927. He discovered that irradiating Drosophila melanogaster with X-rays caused a massive increase in the mutation rate by $\approx 15,000 \%$ over base levels (Muller, 1927). At almost the same time, Stadler independently showed that X-rays and gamma radiation had similar effects on barley and maize (Stadler, 1928a, 1928b). The value of these physical mutagens to plant breeding was quickly recognized (Gates, 1930). Approximately two decades later, the first chemical mutagens were discovered in the United Kingdom and Union of Soviet Socialist Republics (Auerbach and Robson, 1946; Rapoport, 1946). Since then, many other mutagens have been discovered, and the effectiveness of these physical and chemical mutagens has been proven by countless experiments (Arunyanart and Soontronyatara, 2002; Loveless, 1958; Tanaka et al., 2010; Wang et al., 1988). Furthermore, more than 3300 mutant plant varieties have been registered in the Food and Agriculture Organization (FAO)/International Atomic Energy Agency (IAEA) Mutant Variety Database, ranging from cereals and oilseed crops to orchids and woody perennials, indicating the widespread use of mutagenesis in modern plant breeding (International Atomic Energy Agency, 2021).

Besides nontargeted mutagens such as $\mathrm{X}$ rays and gamma rays that merely increase the random mutation rate, tools that allow direct modification of plant DNA plant by genetic engineering are available. The first use of such a tool was in 1983, when Barton et al. (1983) successfully modified and regenerated tobacco using Agrobacterium tumefaciens as a vector to introduce exogenous DNA. Subsequently, a number of other tools were developed, among which are zinc finger nucleases, TALENs, and CRISPR-Cas9 (Khurshid et al., 2018; Shukla et al., 2009; Zhang et al., 2013). Although these methods allow efficient and directed modification of plant DNA, their use has been very limited in ornamental plant breeding for a few reasons. First, there is comparatively little knowledge of procedures for the transformation and regeneration of many ornamental species, and many that have been studied have proved exceedingly challenging. Second, genetic engineering is economically infeasible for the majority of ornamental species because of the high regulatory and development costs (Backes, 2013; Schum, 2003; Vining et al., 2012). Finally, there is little available sequence information available for ornamentals, which is required for targeted mutation or gene editing.

Because genetic engineering is largely impractical, ornamental plant breeding in particular has benefitted from the use of random mutagenesis. It is often difficult to hybridize existing cultivars with other germplasm; therefore, other ways of introducing genetic variation are needed (Van Tuyl and Lim, 2003). Additionally, vegetative propagation is common in ornamentals, which means that mutants with novel phenotypes are relatively easily maintained.

Although very useful, the application of random mutagenesis in the breeding of ornamental plants is not as straightforward as it often seems. Several factors should be considered when choosing from the available mutagens. Some require sources of radiation, whereas a place to work safely with chemicals is the only requirement for others. 
Cost and the plant material to be treated are also factors that should be considered. Besides deciding which mutagen to use, choosing the optimal treatment conditions and organ (e.g., seed, vegetative meristems, pollen) is critical to success. The large variety of ornamental species and the many genotypes within these species could all respond differently to the same treatment conditions because of varying (radio)sensitivity to mutagens (Jiang et al., 2014). Therefore, data from previous studies can be helpful when choosing the optimal mutagen and treatment conditions for new species or cultivars.

Although mutagenesis in agronomic crops has been comprehensively reviewed, there has been less focus on the mutation breeding of ornamentals (Daskalov, 1986; Goyal and Khan, 2010; Khan and Tyagi, 2013; Roebbelen, 1990; Wani et al., 2013). The goals of this review were to provide an overview of the most commonly used mutagens for a large variety of ornamental genera, to discuss the advantages and disadvantages of each mutagen, to provide some examples of resulting mutations, and to discuss possible future research opportunities that could help to improve mutation breeding methods. English and Dutch publications found by searching Google Scholar, ScienceDirect, and SpringerLink were used, with no restrictions regarding the date of publication.

This review was limited to random mutagenesis. CRISPR-CAS9 and other types of genetic engineering are not included because of their limited use in ornamental breeding. The current techniques used for ethyl methanesulfonate (EMS) and other alkylating agents, $\mathrm{X}$-rays, gamma rays, fast neutron irradiation, and heavy ion irradiation and their experiences in ornamental annuals/biennials and herbaceous and woody perennials are reviewed and discussed.

\section{EMS and Other Alkylating Agents}

The widespread use of alkylating agents such as EMS in ornamental plant breeding has been observed since their discovery in 1946 . Although many chemicals such as $N$-methyl$N^{\prime}$-nitro- $N$-nitrosoguanidine, $N$-ethyl- $N$-nitrosourea, and dimethylnitrosamine can also be used, EMS is by far the most common because of its mutagenic efficiency (ratio of mutations to deleterious effects (Gautam et al., 1992; Girija and Dhanavel, 2009; Yamaguchi et al., 2009), relatively low cost, and high availability (Gichner and Velemínský, 1967; Montesano et al., 1979; Schendel and Michaeli, 1984; Talebi et al., 2012).

The mechanism by which EMS modifies DNA is based on the alkylation of guanine, resulting in $\mathrm{G}: \mathrm{C}$ to $\mathrm{A}: \mathrm{T}$ substitutions. This causes point mutations that are randomly distributed throughout the entire genome (Greene et al., 2003), resulting in single nucleotide polymorphisms (SNPs). Furthermore, EMS causes fewer deletions than physical mutagens (Koornneef et al., 1982). Therefore, chemical mutagens such as EMS are useful for inducing missense or nonsense mutations, resulting in change-of-function or occasionally loss-offunction mutants (Shikazono et al., 2005).

Seeds are typically treated with a buffer solution containing EMS. The treatment concentrations and durations vary widely among taxa and even within the same species because different genotypes may respond differently to treatment. Deleterious effects can be caused by EMS, such as lethality, sterility, and a lower ability to regenerate plants from tissues such as floral pedicels (Latado et al., 2004; Roychowdhury and Tah, 2011). Reduced fertility resulting from the treatment of some weedy or invasive species is desirable and at least as important as other phenotypic changes. Pilot experiments to determine the optimal treatment conditions, usually a combination of concentration and duration resulting in 50\% survival [(median lethal dose $\left.\left(\mathrm{LD}_{50}\right)\right]$, are always advised (Berenschot et al., 2008; Hohmann et al., 2005; Kim et al., 2006; Napoli and Ruehle 1996). In addition to seeds, in vitro treatments have been applied to nodal segments and ray florets in chrysanthemum (Padmadevi and Jawaharlal, 2011).

\section{Annuals and Biennials}

EMS has been used for several annual and biennial ornamental genera (Table 1). Seeds were treated in every case except for Begonia, concentrations have ranged from $0.10 \%$ to $1.20 \%$, with an outlier at $40 \%$, and treatment durations are commonly between 4 and 24 h. Kashikar and Khalatkar (1981) observed flower color changes in the M1 and M2 generations of white flowering Petunia $\times$ hybrida. Several different shades of violet were found in the M1 generation, and colors ranging from pink to pale blueish magenta were found in the M2 generation. M1 mutants displaying dwarfism and abnormal leaf morphology were found in Antirrhinum majus (Heffron et al., 2006). In addition to changing flower color and other morphological traits, EMS has also been used to create mutants with resistance against pathogens, as shown by Chen et al. (2014) who obtained Begonia $\times$ hiemalis mutants that were resistant to stem rot caused by Rhizoctonia solani.

\section{Herbaceous Perennials}

A few nonwoody perennial ornamental species have also been treated with EMS, with the economically important genus Chrysanthemum being the most common (Table 1) (Datta and Chakrabarty, 2005). Several Chrysanthemum tissues were used, with concentrations ranging from $0.02 \%$ to $1.03 \%$ and durations ranging from 1 to $5 \mathrm{~h}$. Other genera were treated with concentrations and durations ranging from $0.10 \%$ to $1.25 \%$ at $10 \mathrm{~min}$ to $24 \mathrm{~h}$ (Table 1). Different tissues, ranging from flower pedicels and leaf segments to seeds and bulbs, were used during these studies. Treatment durations and concentrations ranged from $10 \mathrm{~min}$ to $24 \mathrm{~h}$ and $0.02 \%$ to $1.25 \%$, respectively. Hossain et al. (2006a) found a salt-tolerant Chrysanthemum morifolium mutant that did not suffer in terms of flower size and number when grown in high-salinity conditions. EMS treatment also led to changes in flower color in chrysanthemum. Latado et al. (2004), for example, treated the dark pink cultivar Ingrid and found mutants with white, yellow, and bronze flowers. EMS also led to an increase in the tepal number from six to eight in Agave amica (Singh et al., 2013). Reductions in plant height and pollen fertility have also been observed (Contreras and Shearer, 2020; Kapadiya et al., 2016; Padmadevi and Jawaharlal, 2011; Tirkey and Singh, 2019).

\section{Woody Trees and Shrubs}

EMS also has been used for woody ornamentals (Table 1). Seeds and other tissues such as cuttings and meristems were used. The treatments consisted of EMS solutions ranging from $0.05 \%$ to $5 \%$ and durations ranging from $1 \mathrm{~h}$ to $48 \mathrm{~h}$. As with the annual, biennial, and herbaceous perennials, many traits were affected. Treatment of Buddleja davidii seeds led to the cultivar Summer Skies, which shows stable variegation along the edges of leaves (Smith and Brand, 2012). Leaf morphology was affected in Weigela and Ribes sanguineum, which, in the case of the latter, led to the cultivar Oregon Snowflake (Contreras and Friddle, 2015; Duron, 1992). Smilansky et al. (1986) observed a decrease in rose petal number and flower size after EMS treatments of cuttings. Flower color mutants that had lower cyanidin and pelargonidin concentrations were also found. Variations observed in Bougainvillea spectabilis included dwarfism, thornlessness, leaf shape, and variegation (Anitha et al., 2017). Ghosh et al. (2019) also observed dwarfism in Jasminum grandiflorum.

EMS is clearly capable of inducing mutations in a large range of species, thus affecting many traits. There is no need for expensive technical equipment, and the procedure is relatively straightforward, thereby making the use of EMS an attractive choice, especially for smaller-scale breeding programs. One disadvantage of using EMS or other chemical mutagens is their inability to penetrate deeply into plant tissues and seeds with thick coats, possibly leading to inconsistent treatments (Van Harten, 1998).

An advantage of EMS is that the mutagenic efficiency is quite high, which means that the number of undesirable mutations is low relative to the total number of mutations (Gautam et al., 1992; Girija and Dhanavel, 2009; Kaul and Bhan, 1977; Wani, 2009). However, the efficiency does typically change with dose and decreases on either side of the optimum. This further emphasizes the importance of determining the optimal dose before treating plants on a large scale.

The efficiency of mutation breeding using EMS may be increased further by using the reverse genetics tool known as targetinginduced local lesions in genomes (TILLING). TILLING combines mutagenesis, commonly using EMS to generate single base substitutions 
Table 1. Ethyl methanesulfontate (EMS) treatment conditions. The genus, mutagen, EMS concentration, treatment duration, median lethal dose (LD $\left.{ }_{50}\right)$ when provided, treated material, and reference are shown for each study. EMS concentrations ranged from $0.02 \%$ to $5 \%$, with one exceptionally high concentration at $40 \%$. Treatment durations ranged from $10 \mathrm{~min}$ to $48 \mathrm{~h}$. In most cases, seeds were treated in many cases; however, other materials such as cuttings have been used.

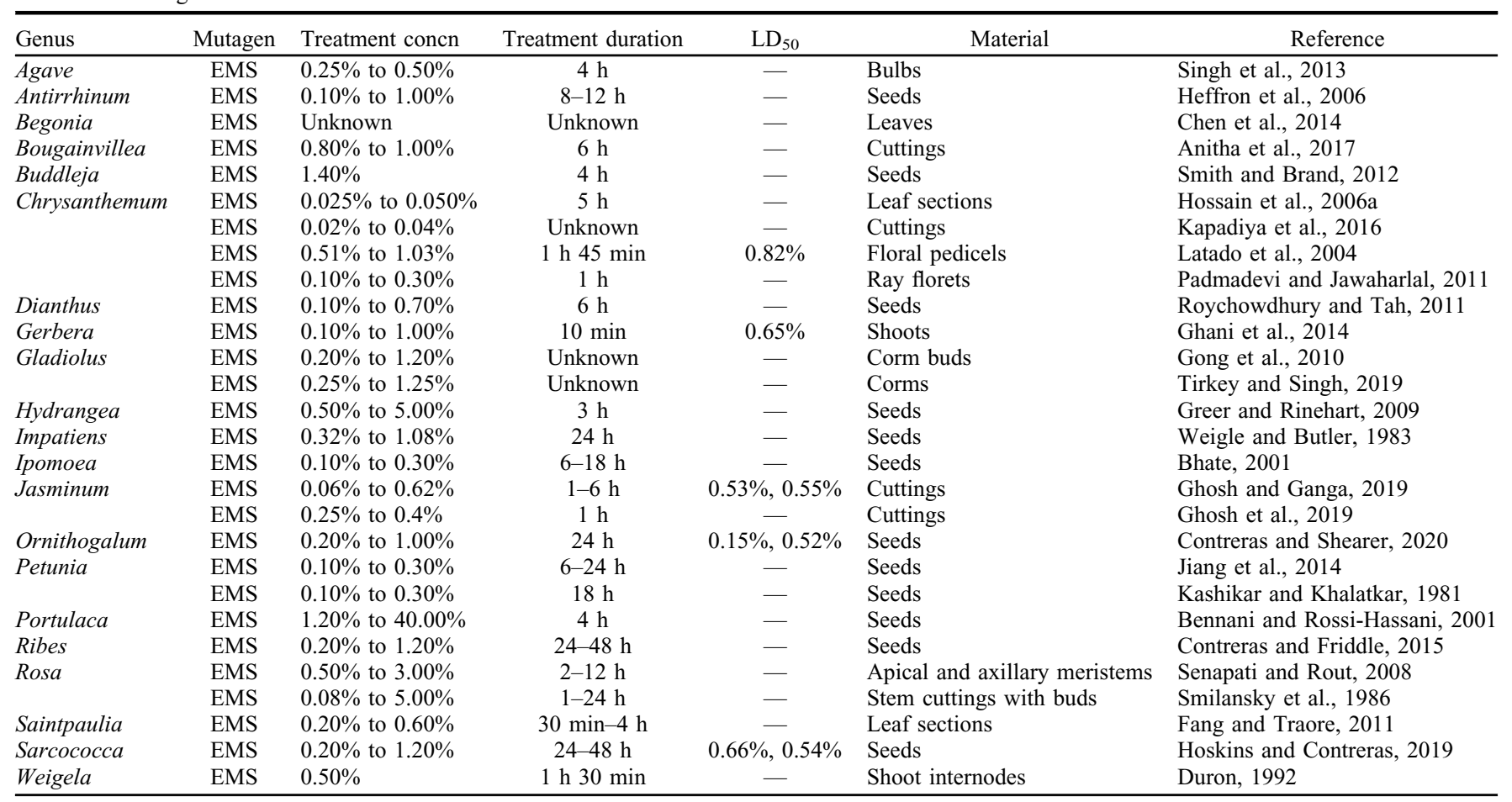

observed as SNPs, with a screening tool to detect mutations in target genes in young plants (McCallum et al., 2000). Several tools are available for detecting the SNPs, including denaturing high-performance liquid chromatography, high-resolution melting, and nextgeneration sequencing (McCallum et al., 2000; Taheri et al., 2017).

TILLING is capable of increasing the efficiency further by allowing the selection of mutants before traits such as flower color or morphology become visible. This could be especially valuable in the case of woody ornamentals, which require several years to reach maturity (Wilde et al., 2012). TILLING also allows for a much larger initial mutant population because the majority of mutants can be discarded after genetic screening. Another advantage is that mutants obtained using TILLING are not considered genetically modified organisms, thus exempting them from expensive regulation and bans (Backes, 2013; Kurowska et al., 2011). One drawback of TILLING is that knowledge of the target genes to be screened is required but is still lacking for most ornamentals. Rinehart et al. (2018) listed a number of possible target genes for Hydrangea macrophylla that were selected based on homology to Arabidopsis genes, but the function of these genes has not been confirmed. Nonetheless, EMS mutagenesis as a part of TILLING might become a very powerful tool for ornamental breeding in the future as sequencing costs continue to decrease. However, as the regulatory landscape changes, site-directed mutagenesis or gene editing may be more efficient.

\section{X-rays and Gamma Rays}

Many mutant varieties have been created using X-rays and gamma rays after Muller (1927) and Stadler (1928a, 1928b) discovered the mutagenic effects of ionizing radiation. Gamma radiation in particular has been popular; approximately half of all mutant varieties registered in the FAO/IAEA Mutant Variety Database were created using gamma rays. Xrays only account for $\approx 17 \%$ of the registered varieties, and chemical mutagenesis has been used for slightly more than 10\% (International Atomic Energy Agency, 2021).

$\mathrm{X}$-ray and gamma ray mutagenesis are based on the direct and indirect interactions of highly energetic electromagnetic radiation with DNA. These interactions usually result in deletions and other chromosomal aberrations by breaking the DNA, with mostly lossof-function mutants as a result (Kodym and Afza, 2003; Maple and Møller, 2007; Oladosu et al., 2016).

For gamma irradiation, plant tissue or seeds are typically treated in gamma chambers or rooms for acute irradiation and gamma fields for chronic irradiation (Bala and Singh, 2013; Datta, 2014; Girija and Dhanavel, 2009). Chronic irradiation, however, is rarely used. The most common gamma source is cobalt- 60 , but others, such as cesium-137, are also effective (Puchooa, 2005). The procedure for X-ray irradiation is similar and uses an X-ray source instead of a gamma source. Dosage is typically measured in kilorads (krad), grays (Gy), or sometimes roentgens (R). Converting among units is simple: 10 $\mathrm{krad}=1 \mathrm{~Gy}$ and $114 \mathrm{R}=1 \mathrm{~Gy}$. A wide range of absorbed radiation doses are used depending on the radiosensitivity of the treated material. Physical mutagens have the same deleterious effects as chemical mutagens. Therefore, it is recommended that the optimal dose, usually close to the $\mathrm{LD}_{50}$, should be determined for a specific subject before starting with irradiation on a large scale (Bala and Singh, 2013; Bhat et al., 2007; Douglas, 1986; Girija and Dhanavel, 2009; Gladstones and Francis, 1965; Puchooa, 2005; Walther and Sauer, 1986a; Webb et al., 2005).

\section{Annuals and Biennials}

Gamma and X-rays have been used to study mutagenesis in a few annual and biennial ornamental genera, with Petunia being the most common (Table 2). For gamma irradiation, the total absorbed doses have ranged from 0.5 to $320 \mathrm{krad}$. A dose of $320 \mathrm{krad}$ is exceptionally high, however; the median maximum dose was $12.5 \mathrm{krad}$. For X-rays, the doses have ranged from 0.22 to $20 \mathrm{krad}$. Seeds are the most commonly irradiated tissues, but others such as leaf discs and cuttings have been used. Many traits were affected. Berenschot et al. (2008) identified a Petunia mutant with a higher density of trichomes and a distinct leaf shape. Venkatachalam and Jayabalan (1997) found zinnias with novel flower colors such as yellow, magenta, and red with white spots in mutants of the cultivar Crimson Red. A Zinnia mutant showing a larger number of whorls in its flowers was also found. Doorenbos and Karper (1975) identified Begonia $\times$ hiemalis mutants displaying dwarfism, petaloid stamens, and 
Table 2. Gamma and X-ray treatment conditions. The genus, mutagen, treatment dose, median lethal dose $\left(\mathrm{LD}_{50}\right)$, treated material, and reference are shown for each study. The treatment dose is shown in kilorads (krad). Doses originally reported in grays or roentgens were converted using the factors 0.1 and 0.877 , respectively. Doses ranged from $0.22 \mathrm{krad}$ to $20 \mathrm{krad}$ for X-rays, with one outlier at $50 \mathrm{krad}$. For gamma rays, the doses ranged from 0.1 to $60 \mathrm{krad}$, with outliers at $140 \mathrm{krad}, 225 \mathrm{krad}$, and $320 \mathrm{krad}$. Cuttings and seeds were often treated, but other materials such as leaf segments, bulbs, and callus were also used.

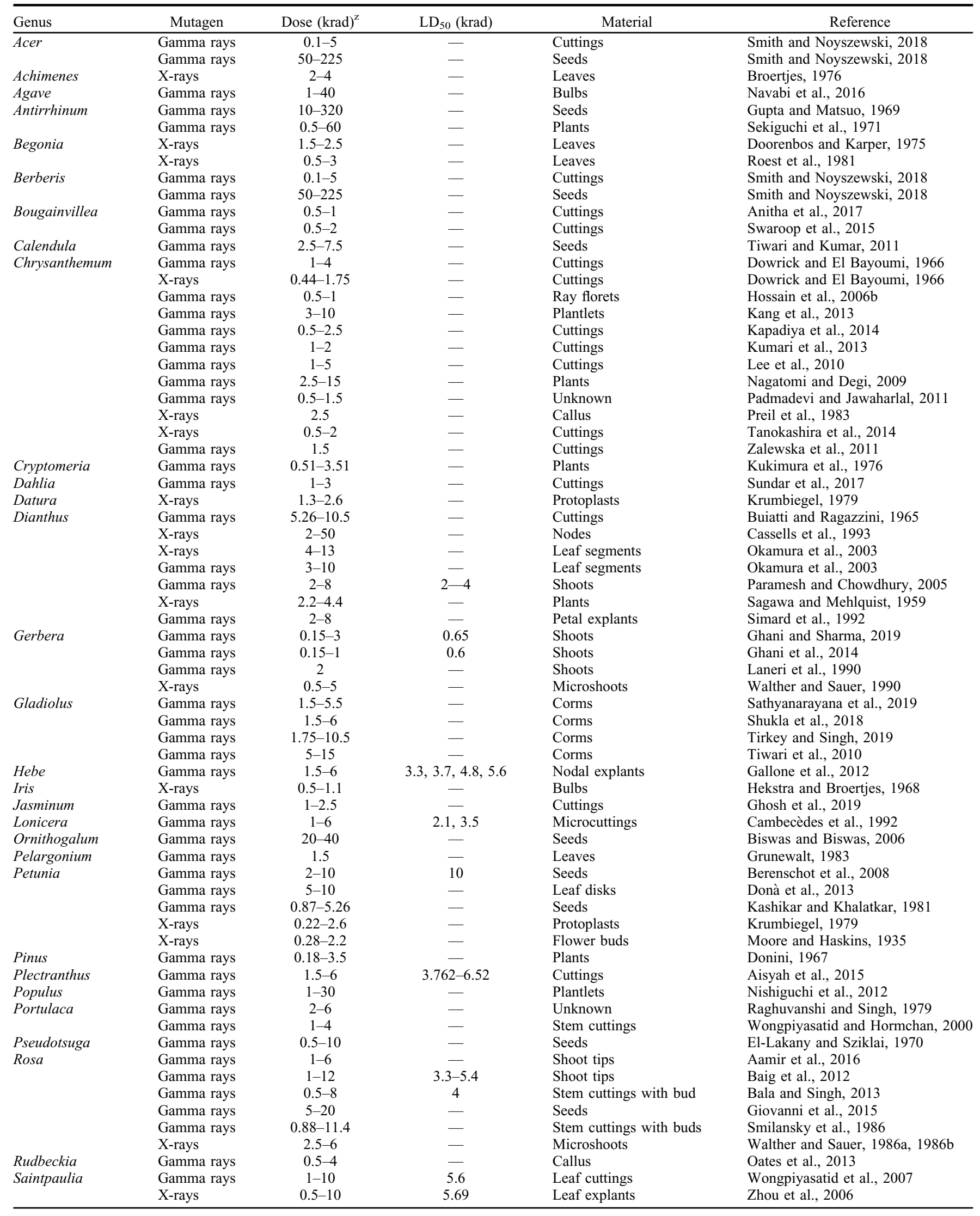


Table 2. (Continued)

\begin{tabular}{|c|c|c|c|c|c|}
\hline Genus & Mutagen & Dose $(\mathrm{krad})^{\mathrm{z}}$ & $\mathrm{LD}_{50}(\mathrm{krad})$ & Material & Reference \\
\hline Sophora & Gamma rays & $20-140$ & - & Seeds & Wang et al., 2017 \\
\hline Tsuga & Gamma rays & $0.5-10$ & - & Seeds & El-Lakany and Sziklai, 1970 \\
\hline \multirow[t]{3}{*}{ Zinnia } & Gamma rays & $7.5-12.5$ & - & Seeds & Pallavi et al., 2017 \\
\hline & $\mathrm{X}$-rays & 20 & - & Seeds & Swarup and Raghava, 1974 \\
\hline & Gamma rays & $2.5-12.5$ & - & Seeds & Venkatachalam and Jayabalan, 1997 \\
\hline
\end{tabular}

${ }^{\mathrm{z}}$ Reported in krad. Conversions to other units are $10 \mathrm{krad}=1 \mathrm{~Gy}$ and $114 \mathrm{R}=1 \mathrm{~Gy}$.

varying leaf colors. Fertility, characterized as the number of seed capsules produced after manual pollination, was reduced in Petunia $\times$ hybrida (Berenschot et al., 2008).

\section{Herbaceous Perennials}

$\mathrm{X}$-rays and gamma rays have been widely used for several herbaceous perennials, with Chrysanthemum being the most commonly treated genus by far (Table 2). The X-ray treatments have consisted of doses ranging from 0.44 to $13 \mathrm{krad}$, with one exceptionally high dose at $50 \mathrm{krad}$. For gamma irradiation, the doses ranged from 0.15 to $15 \mathrm{krad}$, with two outliers at $40 \mathrm{krad}$. Many different tissues were used during these studies. For Chrysanthemum alone, the tissues ranged from cuttings and whole plants to individual cells and ray florets. For other genera, corms, leaf cuttings, and bulbs were used. Surprisingly, seeds were not used in the reviewed studies. Regarding annuals and biennials, many morphological traits were affected. Preil et al. (1983) selected two Chrysanthemum mutants that were tolerant to low temperatures. Lee et al. (2010) irradiated cuttings of the Chrysanthemum cultivar Beakma and found a mutant that did not form a hollow stem when grown in high summer temperatures, leading to plants with stronger stems that are easier to handle. A Gerbera jamesonii mutant that was tolerant to powdery mildew was found by Ghani and Sharma (2019). X-ray irradiation restored male fertility in Dianthus caryophyllus (Sagawa and Mehlquist, 1959); however, Biswas and Biswas (2006) were able to induce partial sterility in Ornithogalum virens. Oates et al. (2013) noticed that treating Rudbeckia subtomentosa callus with relatively low levels of gamma radiation resulted in high survival and a good number of mutations, including reduced height and good flower form. A large variety of changes in flower color as well as flower morphology were found in most of the other genera, and traits like vase life can also be improved, as shown by Shukla et al. (2018).

\section{Woody Trees and Shrubs}

Many diverse woody genera have been treated with gamma or X-rays (Table 2). Sparrow et al., (1968) determined the gamma radiation $\mathrm{LD}_{50}$ doses for 28 woody plant species and predicted the $\mathrm{LD}_{50}$ for another 190 species based on their interphase chromosome volumes, although the authors concede there exists wide variations because of timing and other factors involved with their method. They did not describe any visible phenotypes resulting from mutations, but the $\mathrm{LD}_{50}$ values provide starting points when trying to determine the optimal dose for any of these species. The aforementioned studies used doses ranging from 0.1 to $40 \mathrm{krad}$ with outliers at 140 and $225 \mathrm{krad}$ for gamma rays and 2.5 to $6 \mathrm{krad}$ for X-rays. Seeds and cuttings were often the choice of tissue to treat, but whole plants and explants were also treated. Different traits were affected by the mutations. A jasmine-like fragrance was found in a Vitex agnus-castus mutant by Ari et al. (2015), who showed that complicated traits like fragrance can also be improved by inducing mutations. Dwarfism was found by Kukimura et al. (1976) in Cryptomeria and in Jasminum (Ghosh et al., 2019). Shorter internodes resulting in lower plant height were also observed in Populus and Rosa (Baig et al., 2012; Nishiguchi et al., 2012). Other variations in Rosa were restoration of fertility and changes in color (orange, pink, etc. compared with red in the original cultivar), possibly because of changes in cyanidin and pelargonidin content (Smilansky et al., 1986).

Although gamma and X-ray irradiation have been very effective mutagens in a large number of plant species, they require more expensive equipment such as gamma sources and X-ray machines. They provide good penetration of tissues and seeds, making it possible to treat material with a higher consistency. They also provide ways to treat fragile tissue, such as pollen grains, that could be damaged by soaking them in chemicals (Oladosu et al., 2016; Predieri and Di Virgilio, 2007; Schum, 2003). Their mutagenic efficiency, however, seems to be relatively low (Gautam et al., 1992; Girija and Dhanavel, 2009; Kaul and Bhan, 1977; Wani, 2009).

There may be a way to increase the efficiency, however, by optimizing not only the total absorbed dose but also the dose rate. Often, only the total absorbed dose is described in treatments and relatively little attention is focused on the dose rate and/or duration of radiation treatment. Acute irradiation (high dose rate/short duration) has been favored over chronic irradiation (low dose rate/long duration) for a long time, but the efficiency of both methods has been debated (Kodym and Afza, 2003). Nagatomi and Degi (2009) showed that chronic gamma irradiation more effectively induced flower color mutants in Chrysanthemum, and Broertjes (1972) showed a similar effect of chronic X-ray irradiation in Saintpaulia. Numerous plant species have been successfully treated with chronic irradiation (Datta, 2012; Nagatomi, 1993; Nagatomi et al., 2000; Richter and Singleton, 1995). Therefore, experimentation with different dose rates and durations may lead to more efficient irradiation protocols for many ornamental species.

\section{Neutrons and Heavy Ions}

Neutron and heavy ion irradiation are being used as alternatives to gamma or X-ray irradiation. Heavy ion irradiation, mostly using carbon ions, has been used in recent years to induce mutations in several plant species (Arase et al., 2011; Kondo et al., 2009; Matsumura et al., 2010; Okamura et al., 2003; Reyes-Borja et al., 2007; Takahashi et al., 2005). Neutron irradiation has also been used as a mutagen, but it has had very limited use in ornamentals (Bolon et al., 2011; Broertjes, 1976; Datta, 2012; Love and Constantin, 1966; Smith and Noyszewski, 2018; Wang et al., 2015).

The mechanism by which neutron and ion irradiation induce mutations is somewhat similar to the way gamma and X-ray irradiation induce mutations. Neutrons and ions collide with DNA, thus causing double-strand breaks and resulting in deletions (Shikazono et al., 2005). As a result, irradiation with neutrons or ions mainly produces loss-of-function mutants.

The ions used for the irradiation of plant tissues are usually accelerated by a cyclotron and sent downrange to the sample (Magori et al., 2010). In addition to choosing the total dose, the energy of the particles themselves can be adjusted by choosing ions of a specific element. Although carbon is often used, irradiation using heavier ions such as argon or iron is also possible. Another way of altering the particle energy of the ions is by forcing the beam to pass through aluminum disks of a certain thickness, thus causing the particles to lose kinetic energy (Ryuto et al., 2008). The particle energy is measured in either mega-electronvolts $(\mathrm{MeV})$ for the total particle energy, or mega-electronvolts per nucleon $(\mathrm{MeV} / \mathrm{u})$. The amount of energy that the ions ultimately deposit in the plant tissue is described by the linear energy transfer (LET) in $\mathrm{keV} / \mu \mathrm{m}$. Doses typically range from 0.01 to $14 \mathrm{krad}$ at LETs ranging from 22.5 to $310 \mathrm{keV} / \mu \mathrm{m}$. As with all mutagens, determining the optimal dose before large-scale irradiation is important.

For neutron irradiation, samples are usually placed near nuclear reactors suitable for neutron irradiation studies (e.g., the UC Davis McClellan Nuclear Research Center 
and the decommissioned Biological Agricultural Reactor Netherlands) (Bogaardt et al., 1965; Kodym and Afza, 2003; Smith and Noyszewski, 2018). The reactors must be designed in such a way that gamma ray contamination can be mostly filtered out. Doses typically range from 0.75 to $14 \mathrm{krad}$. Various types of neutrons, usually thermal or fast neutrons, can be used (Burdick, 1956). These neutrons differ in their kinetic energy levels; thermal neutrons have energies less than 1 $\mathrm{eV}$, whereas fast neutrons have energies more than $1 \mathrm{MeV}$ (Carron, 2006). Attention should be focused on the fact that materials treated with fast neutrons remain radioactive after treatment; therefore, the materials must be maintained until they are safe to handle (Van Harten, 1998). Again, the optimal dose for specific subjects should be determined before large-scale irradiation treatments.

\section{Annuals and Biennials}

Only a few annual or biennial genera have been treated with ion beams, and neutron beams have not been used at all (Table 3). The heavy ion doses used during these studies have ranged from 0.1 to $8 \mathrm{krad}$ at LETs from 22.5 to $76 \mathrm{keV} / \mu \mathrm{m}$. The tissues used for ion beam irradiation vary. Shoot cultures and apical meristems have been used, but cuttings with nodes and leaves are suitable irradiation targets as well. Flower color is often affected. Ogawa et al. (2014) found Limonium mutants showing lighter, darker, or more reddish shades of purple compared with the original purple flowers. Miyazaki et al. (2006) found similar Torenia mutants showing pale or dark pink flowers compared with blue in the wild type. They also revealed that the pink color likely resulted from the inhibition of dihydromyricetin biosynthesis, thus preventing build-up of the anthocyanidins delphinidin, petunidin, and malvidin. Other traits such as variegation in Petunia and sterility in Verbena were observed (Kanaya et al., 2008; Miyazaki et al., 2002).

\section{Herbaceous Perennials}

A much larger number of herbaceous perennial genera have been treated with ion beam and neutron irradiation, with Chrysanthemum again being the most common (Table $3)$. Treatment conditions included ion doses ranging from 0.01 to $10 \mathrm{krad}$ at LETs ranging from 22.5 to $310 \mathrm{keV} / \mu \mathrm{m}$. Only Achimenes was treated with neutrons at doses ranging from 0.75 to $2 \mathrm{krad}$. Tissues such as ray florets, leaf segments, callus, petioles, and buds were used as targets. Seeds were used in one case, too. Basic morphological traits such as plant size (dwarfism), leaf shape, flower color, flower size, and flower shape were affected in the majority of mutants. Sugiyama et al. (2008a) found sterile Cyclamen mutants. A Chrysanthemum mutant that flowered early and under low temperatures was also identified (Sakamoto et al., 2016).

\section{Woody Trees and Shrubs}

Relatively few woody genera were treated with neutron or ion beam irradiation (Table 3 ). Ion beam doses ranging from 0.5 to $14 \mathrm{krad}$ were used. LETs were mostly not reported, except for two cases in which the LET was $\approx 23 \mathrm{keV} / \mu \mathrm{m}$. Neutron irradiation doses ranged from 2 to $14 \mathrm{krad}$. Seeds were most commonly used as irradiation targets, but scions, stem cuttings, and buds have been used. Among the affected traits were flower color in Prunus and Rosa and plant size (dwarfism) in Spiraea and Hydrangea. Hayashi et al. (2019) found that a Prunus mutant in 2007, which flowered twice during a single year, did not require a cold period for flowering and

Table 3. Neutron and heavy ion treatment conditions. The genus, mutagen, treatment conditions, treated material, and reference are shown for each study. For the treatment conditions, the dose is shown in kilorads (krad). Ion particle energy in either mega-electronvolts per nucleon (MeV/u) or total energy in $\mathrm{MeV}$ is shown. The particle linear energy transfer (LET) in kilo-electronvolts per micrometer (keV/ $\mu \mathrm{m})$ is also shown for ion beam treatments. Doses ranged from $0.75 \mathrm{krad}$ to $14 \mathrm{krad}$ for neutron irradiation treatments. For ion beam treatments, the doses ranged from $0.01 \mathrm{krad}$ to 14 krad at LETs ranging from 22.5 to $310 \mathrm{keV} / \mu \mathrm{m}$. Treated materials included leaves, cuttings, ray florets, callus, and many others.

\begin{tabular}{|c|c|c|c|c|c|}
\hline Genus & Mutagen & Dose & $\mathrm{LD}_{50}$ & Material & Reference \\
\hline Acer & Neutrons & $2-14 \mathrm{krad}$ & - & Seeds & Smith and Noyszewski, 2018 \\
\hline Achimenes & Neutrons & $0.75-2 \mathrm{krad}$ & - & Leaves & Broertjes, 1976 \\
\hline Berberis & Neutrons & $2-14 \mathrm{krad}$ & - & Seeds & Smith and Noyszewski, 2018 \\
\hline \multirow[t]{8}{*}{ Chrysanthemum } & Ion beam & $1 \mathrm{krad}$, unknown, $23 \mathrm{keV} / \mu \mathrm{m}$ & - & Scions & Hisamura et al., 2016 \\
\hline & Ion beam & $0.1-0.8 \mathrm{krad}, 220 \mathrm{MeV}, 122 \mathrm{keV} / \mu \mathrm{m}$ & - & Ray florets and leaf explants & Matsumura et al., 2010 \\
\hline & Ion beam & $0.1-0.5 \mathrm{krad}, 446 \mathrm{MeV} / \mathrm{u}, 93 \mathrm{keV} / \mu \mathrm{m}$ & - & Leaf segments and ray florets & Okamura et al., 2015 \\
\hline & Ion beam & $0.3-0.6 \mathrm{krad}$, unknown, $22.6 \mathrm{keV} / \mu \mathrm{m}$ & - & Cuttings & Sakamoto et al., 2016 \\
\hline & Ion beam & $0.1-2 \mathrm{krad}, 135 \mathrm{MeV} / \mathrm{u}, 23 \mathrm{keV} / \mu \mathrm{m}$ & - & Stem segments & Suzuki et al., 2005 \\
\hline & Ion beam & $0.2-0.5 \mathrm{krad}$, unknown, $23 / 62 / 280 \mathrm{keV} / \mu \mathrm{m}$ & - & Cuttings & Tanokashira et al., 2014 \\
\hline & Ion beam & $0.01-0.3 \mathrm{krad}$, unknown, $23 / 310 \mathrm{keV} / \mu \mathrm{m}$ & - & Leaf blades & Tanokashira et al., 2016 \\
\hline & Ion beam & $0.3-0.6 \mathrm{krad}, 135 \mathrm{MeV} / \mathrm{u}, 22.5 \mathrm{keV} / \mu \mathrm{m}$ & - & Stem segments & Wakita et al., 2008 \\
\hline \multirow[t]{3}{*}{ Cyclamen } & Ion beam & 0-5 krad, 220/320 MeV, unknown & - & Petioles & Ishizaka et al., 2012 \\
\hline & Ion beam & $0.05-1.6 \mathrm{krad}, 320 \mathrm{MeV}$, unknown & - & Petioles & Kondo et al., 2009 \\
\hline & Ion beam & $1-8 \mathrm{krad}, 1.62 \mathrm{GeV}, 23 \mathrm{keV} / \mu \mathrm{m}$ & - & $\begin{array}{l}\text { Callus, somatic embryos, } \\
\text { plantlets, tubers }\end{array}$ & Sugiyama et al., 2008a \\
\hline Dahlia & Ion beam & 0.5-10 krad, unknown, unknown & - & Shoots & Hamatani et al., 2001 \\
\hline \multirow[t]{3}{*}{ Dianthus } & Ion beam & $0.5-3 \mathrm{krad}, 220 \mathrm{MeV}$, unknown & - & Leaf segments & Okamura et al., 2003 \\
\hline & Ion beam & $0.7-2 \mathrm{krad}, 320 \mathrm{MeV}, 76 \mathrm{keV} / \mu \mathrm{m}$ & - & Petals & Okamura et al., 2013 \\
\hline & Ion beam & $2-8 \mathrm{krad}, 135 \mathrm{MeV} / \mathrm{u}, 23 \mathrm{keV} / \mu \mathrm{m}$ & - & Stem segments & Sugiyama et al., $2008 \mathrm{~b}$ \\
\hline Hydrangea & Ion beam & 1-5 krad, $100 \mathrm{MeV}$, unknown & - & Seeds & Kudo et al., 1998 \\
\hline Limonium & Ion beam & $0.5-3 \mathrm{krad}$, unknown, $23 \mathrm{keV} / \mu \mathrm{m}$ & - & Shoot cultures & Ogawa et al., 2014 \\
\hline Pelargonium & Ion beam & $1-4 \mathrm{krad}, 80 \mathrm{Mev} / \mathrm{u}, 34 \mathrm{keV} / \mu \mathrm{m}$ & - & Buds & Yu et al., 2016 \\
\hline \multirow[t]{2}{*}{ Petunia } & Ion beam & $0-3 \mathrm{krad}, 320 \mathrm{MeV}, 76 \mathrm{keV} / \mu \mathrm{m}$ & - & Shoot apical meristem & Hase et al., 2010 \\
\hline & Ion beam & $0.1-2 \mathrm{krad}, 135 \mathrm{MeV} / \mathrm{u}$, unknown & - & Nodal cuttings & Miyazaki et al., 2002 \\
\hline Populus & Ion beam & 0-3 krad, unknown, unknown & - & Explants & Biswas et al., 2013 \\
\hline \multirow[t]{2}{*}{ Prunus } & Ion beam & $0.5-2 \mathrm{krad}, 135 \mathrm{MeV} / \mathrm{u}, 23 \mathrm{keV} / \mu \mathrm{m}$ & - & Scions & Hayashi et al., 2019 \\
\hline & Ion beam & $1-2 \mathrm{krad}, 135 \mathrm{MeV} / \mathrm{u}, 22.6 \mathrm{keV} / \mu \mathrm{m}$ & - & Scions & Ishii et al., 2009 \\
\hline \multirow[t]{2}{*}{ Rosa } & Ion beam & $1-5 \mathrm{krad}, 135 \mathrm{MeV} / \mathrm{u}$, unknown & - & Buds & Hara et al., 2003 \\
\hline & Ion beam & $0.5-10 \mathrm{krad}, 100 / 220 \mathrm{MeV}$, unknown & $20,5-7.5 \mathrm{krad}$ & Stem cuttings with bud & Yamaguchi et al., 2003 \\
\hline Saintpaulia & Ion beam & $0.5-8 \mathrm{krad}, 960 \mathrm{MeV}$, unknown & $2.52,2.32 \mathrm{krad}$ & Leaf explants & Zhou et al., 2006 \\
\hline Sandersonia & Ion beam & 2-10 krad, unknown, unknown & - & Seeds & Horita et al., 2002 \\
\hline Spiraea & Ion beam & $0.5-14 \mathrm{krad}, 220 \mathrm{MeV}$, unknown & - & Seeds & Iizuka et al., 2001 \\
\hline \multirow[t]{2}{*}{ Torenia } & Ion beam & 0.5-5 krad, unknown, unknown & - & Leaves and internodes & Miyazaki et al., 2006 \\
\hline & Ion beam & $\begin{array}{l}0.5-8 \mathrm{krad}, 1.62 / 2.70 \mathrm{GeV} \\
22.5 / 61.5 \mathrm{keV} / \mu \mathrm{m}\end{array}$ & - & Leaf disks & Sasaki et al., 2008 \\
\hline Tricyrtis & Ion beam & $0.5-5 \mathrm{krad}, 135 \mathrm{MeV} / \mathrm{u}, 23 \mathrm{keV} / \mu \mathrm{m}$ & - & Callus & Nakano et al., 2010 \\
\hline Verbena & Ion beam & $0.1-1 \mathrm{krad}, 1.89 \mathrm{GeV}, 31 \mathrm{keV} / \mu \mathrm{m}$ & - & Nodes & Kanaya et al., 2008 \\
\hline
\end{tabular}

$\mathrm{LD}_{50}=$ median lethal dose. 
produced three-times the number of flowers of the original variety if the mutant was exposed to cold winter temperatures. This mutant was named 'Nishina Otome' and commercially released in 2010. Smith and Noyszewski (2018) found several Acer mutants that did not flower and, thus, produced no seeds. They also found a Berberis mutant that did flower; nonetheless, it produced nonviable seeds. These mutants are still being evaluated but could provide solutions for mitigating the invasiveness of non-native Acer and Berberis species in North America.

Although neutron and ion beams have not yet been used as much as gamma rays, they are clearly suitable as mutagens in many ornamental plants. They offer the same high penetration of plant tissue and seeds as other physical mutagens, but they do so at seemingly higher efficiency. The reason for this high level of mutagenic efficiency seems to be the high energy levels associated with neutrons and ions. Whereas gamma rays and Xrays consist of photons, neutron and ion beams consist of particles. The amount of concentrated energy that is deposited in plant tissue by these photons or particles is quantified by the LET. The LET values of accelerated ions are much higher than those of gamma rays and X-rays. Whereas the LETs of ions typically range from 22 to $651 \mathrm{keV} /$ $\mu \mathrm{m}$, depending on the type of ion and its kinetic energy, the LETs of gamma and Xrays are only 0.2 and $2 \mathrm{keV} / \mu \mathrm{m}$, respectively (Kazama et al., 2008, 2011; Ryuto et al., 2008). Therefore, the biological effects of ion beams are much stronger. Although gamma and X-ray irradiation mainly cause small deletions, ion beams cause much larger deletions (Hirano et al., 2015; Morita et al., 2009). Neutrons are also classified as high LET radiation and cause deletions ranging from a small number of basepairs to multiple megabases (Li et al., 2001; Men et al., 2002). As a result, neutron and ion irradiation can provide a good mutation rate at lower doses (Shikazono et al., 2005). These properties also seem to increase the mutagenic efficiency, resulting in fewer deleterious mutations (Yamaguchi et al., 2009). Therefore, moving from gamma irradiation to heavy ion or neutron irradiation as the preferred physical mutagen may lead to more efficient mutagenesis.

\section{Stability of Resulting Mutants}

Regardless of the choice of mutagen and $\operatorname{organ}(\mathrm{s})$ treated, chimeras are a common result. Chimeras are often unstable and revert to the wild type. A common example is leaf variegation, in which a portion of a histogenic layer (mericlinal), a portion of multiple histogenic layers (sectorial), or all of a histogenic layer (periclinal) is mutated. Such chimeras and their use in horticulture have been extensively treated elsewhere (Marcotrigiano, 1997). For resulting mutations to be useful, the breeder must understand how to stabilize the trait of interest to allow it to remain true-totype during serial propagation in the case of asexually propagated crops, or it must be expressed through the LII (germ layer) histogenic layer. Often, successive phytomeres will variably express variegation and allow propagation of stems above which the trait appears stabilized. Hoskins and Contreras (2019) reported an example using Sarcococca confuse, in which an unstable "blotchy" variegation was allowed to continue growing and ultimately stabilized to a uniform chartreuse leaf type that remained stable after clonal propagation and also yielded true-to-type seed, although the latter is attributable to apomixis as much as an LII histogenic layer containing the trait. Even if the trait appears stable, there does exist the long-term prospect for reversion as evidence from the numerous cultivars that exhibit regular reversion in the ornamental trade. Seed propagation, independent of apomixis, represents a more reliable method of stabilizing the trait but does require the mutation present in the LII histogenic layer.

\section{Conclusions}

Several factors should be considered when choosing mutagen and treatment conditions. Although chemical mutagens are relatively inexpensive and require little technical equipment, they are regarded as having inferior ability to penetrate deeply into plant tissue or thick seeds (Van Harten, 1998). However, physical mutagens provide consistent treatments but require access to radiation sources, such as X-ray machines, gamma sources, particle accelerators, or nuclear reactors. Other advantages of physical mutagens include easy post-treatment handling of plant tissue or seeds, the ability to treat pollen grains and other fragile materials, and the lack of toxic and carcinogenic waste (Oladosu et al., 2016; Predieri and Di Virgilio, 2007; Schum, 2003). Another reason why EMS or other chemicals may be preferred in some cases is the fact that they mostly cause single base substitutions, possibly resulting in a series of phenotypically distinct change-offunction mutants for a particular trait (Greene et al., 2003; Shikazono et al., 2005). In contrast, physical mutagens usually cause deletions resulting in loss-of-function mutants (Kodym and Afza, 2003; Koornneef et al., 1982; Maple and Møller, 2007; Oladosu et al., 2016). Previously reported experiences with a large number of ornamental genera are valuable when starting mutation breeding for a new species or cultivar. Initial doses can be based on those experiences; thereafter, the treatment conditions may be fine-tuned.

In addition to the discussed advantages and disadvantages, different mutagens have different mutagenic efficiencies. Although gamma radiation has been the most common mutagen to date by far, multiple studies have shown that the efficiency of gamma rays is lower than that of EMS (Gautam et al., 1992; Girija and Dhanavel, 2009; Kaul and Bhan, 1977; Wani, 2009). There are options to improve efficiency, however. For gamma and, possibly, X-ray irradiation, the efficiency may be increased by irradiating plant tissue or seeds at lower dose rates for a longer amount of time. Neutron and heavy ion irradiation are also viable options, providing the same high penetration as traditional physical mutagens at higher efficiencies. Chemical mutagenesis may be improved by combining the use of EMS with genetic screening in a process known as TILLING.

There are many options when it comes to effective mutagens for ornamental plant breeding, and the value of random mutagenesis is underlined by the large number of entries in the mutant variety database. Although genetic engineering is becoming more accessible, it is often too expensive for use in ornamental breeding because of regulatory and development costs. Furthermore, knowledge of the procedures for modification and regeneration of ornamentals is often lacking. As a result, random mutagenesis will remain an important source of genetic diversity for the foreseeable future, with many opportunities to improve existing methods.

\section{Literature Cited}

Aamir, S.S., M.M.Q. Baig, T. Ahmad, A. Ghafoor, I.A. Hafiz, N.A. Abbasi, I. Ali, and M. Yaseen. 2016. Molecular and morphological characterization of rose mutants produced via in vitro mutagenesis. Philipp. Agr. Sci. 99:25-33.

Aisyah, S.I., Y. Marthin, and M.R.M. Damanik. 2015. Improvement of coleus performance through mutation induction using gamma ray irradiation. J. Trop. Crop Sci. 2:26-32, doi: 10.29244/jtcs.2.1.26-32.

Anitha, K., R. Surendranath, M. Jawaharlal, and M. Ganga. 2017. Mutagenic effectiveness and efficiency of gamma $(\gamma)$ rays and ethyl methane sulphonate on Bougainvillea spectabilis Willd. (cv. Lalbagh). Intl. J. Bio-resource Stress Mgt. 8:247-256, doi: 10.23910/IJBSM/2017.8.2.1634.

Arase, S., Y. Hase, J. Abe, M. Kasai, T. Yamada, K. Kitamura, I. Narumi, A. Tanaka, and A. Kanazawa. 2011. Optimization of ion-beam irradiation for mutagenesis in soybean: Effects on plant growth and production of visibly altered mutants. Plant Biotechnol. 28:323-329, doi: 10.5511/plantbiotechnology.11.0111a.

Ari, E., H. Djapo, N. Mutlu, E. Gurbuz, and O. Karaguzel. 2015. Creation of variation through gamma irradiation and polyploidization in Vitex agnus-castus L. Scientia Hort. 195:74-81, doi: 10.1016/j.scienta.2015.08.039.

Arunyanart, S. and S. Soontronyatara. 2002. Mutation induction by $\gamma$ and X-ray irradiation in tissue cultured lotus. Plant Cell Tissue Organ Cult. 70:119-122, doi: 10.1023/A:1016021627832.

Auerbach, C. and J.M. Robson. 1946. Chemical production of mutations. Nature 157:302, doi: 10.1038/157302a0.

Backes, G. 2013. TILLING and EcoTILLING, p. 145-165. In: T. Lübberstedt and R. Varshney (eds.). Diagnostics in plant breeding. Springer, Dordrecht, doi: 10.1007/978-94-007-5687-8_7.

Baig, M.M.Q., I.A. Hafiz, N.A. Abbasi, M Yaseen, Z. Akram, and D.J. Donnely. 2012. Reduced-stature Rosa species through in vitro mutagenesis. Can. J. Plant. Sci. 92:1049-1055, doi: 10.4141/cjps2011-199.

Bala, M. and K.P. Singh. 2013. In vitro mutagenesis of rose (Rosa hybrida L.) explants using gamma-radiation to induce novel flower colour mutations. J. Hort. Sci. Biotechnol. 88:462-468, doi: 10.1080/14620316.2013.11512992.

Barton, K.A., A.N. Binns, A.J.M. Matzke, and M.D. Chilton. 1983. Regeneration of intact 
tobacco plants containing full length copies of genetically engineered t-DNA, and transmission of t-DNA to R1 progeny. Cell 32:1033-1043, doi: 10.1016/0092-8674(83)90288-X.

Bennani, F. and B.D. Rossi-Hassani. 2001. Seed mutagenesis in Portulaca grandiflora (Hook), INIS-XA-427. International Atomic Energy Agency, Vienna.

Berenschot, A.S., M.I. Zucchi, A. Tulmann-Neto, and V. Quecini. 2008. Mutagenesis in Petunia $\times$ hybrida Vilm. and isolation of a novel morphological mutant. Brazilian J. Plant Physiol. 20:95-103, doi: 10.1590/S1677-04202008000 200002.

Bhat, R.S., N.M. Upadhyaya, A. Chaudhury, C. Raghavan, F. Qiu, H. Wang, J. Wu, K. McNally, H. Leung, B. Till, S. Henikoff, and L. Comai. 2007. Chemical- and irradiation-induced mutants and TILLING, p. 148-180. In: N.M. Upadhyaya (ed.). Rice functional genomics. Springer, New York, NY, doi: 10.1007/0-387-48914-2 8.

Bhate, R.H. 2001. Chemically induced floral morphological mutations in two cultivars of Ipomoea purpurea (L.). Roth. Scientia Hort. 88:133-145, doi: 10.1016/S0304-4238(00)00221-1.

Biswas, K.K., T. Mohri, S. Kogawara, I. Narumi, and Y. Oono. 2013. Developing protocol for screening of drought/salt tolerant mutants with ion beam mutagenesis in Populus sp. JAEA Takasaki Annual Report 2011. JAEA, Tōkai.

Biswas, S.C. and A.K. Biswas. 2006. Cytogenetic characterization of induced sterility in Ornithogalum virens L. Cytologia (Tokyo) 71:119-123, doi: 10.1508/cytologia.71.119.

Bogaardt, M., J. Coehoorn, W. Hofman, and W.W. Nijs. 1965. The Biological Agricultural Reactor Netherlands (BARN). Proc. Third Intl. Conf. Peaceful Uses Atomic Energy 7:187-193.

Bolon, Y., W.J. Haun, W.W. Xu, D. Grant, M.G. Stacey, R.T. Nelson, D.J. Gerhardt, J.A. Jeddeloh, G. Stacey, G.J. Muehlbauer, J.H. Orf, S.L. Naeve, R.M. Stupar, and C.P. Vance. 2011. Phenotypic and genomic analyses of a fast neutron mutant population resource in soybean. Plant Physiol. 156:240-253, doi: 10.1104/ pp.110.170811.

Broertjes, C. 1972. Use in plant breeding of acute, chronic or fractioned doses of X-rays or fast neutrons as illustrated with leaves of Saintpaulia. Wageningen Univ. Res., Wageningen, $\mathrm{PhD}$ Diss

Broertjes, C. 1976. Mutation breeding of autotetraploid Achimenes cultivars. Euphytica 25:297-304, doi: 10.1007/BF00041560.

Buiatti, M. and R. Ragazzini. 1965. Gamma-ray induced changes in the carnation Dianthus caryophyllus L. Radiat. Bot. 5:99-105, doi: 10.1016/S0033-7560(65)80029-1.

Burdick, A.B. 1956. Mutagenic effect of thermal neutrons on wet and dry tomato seed. Nature 178:360-361, doi: 10.1038/178360a0.

Cambecèdes, J., M. Duron, L. Decourtye, and R. Jalouzot. 1992. Methodology of in vitro gamma rays irradiations from Lonicera species; mutant description and biochemical characterization. Acta Hort. 320:119-126, doi: 10.17660/ ActaHortic.1992.320.16.

Carron, N.J. 2006. An introduction to the passage of energetic particles through matter. CRC Press, Boca Raton, Fla.

Cassells, A.C., C. Walsh, and C. Periappuram. 1993. Diplontic selection as a positive factor in determining the fitness of mutants of Dianthus 'Mystère' derived from X-irradiation of nodes in in vitro culture. Euphytica 70:167-174, doi: 10.1007/BF00023756.

Chandler, R.F. 1992. An adventure in applied science: A history of the international rice research institute. International Rice Research Institute, Manila.

Chen, Y., Y. Zhang, S. Yuan, H. Liu, X. Zeng, and H. Zhang. 2014. Ethyl methane sulfonate induced disease resistance in Begonia $\times$ hiemalis Fotsch. Hort. Environ. Biotechnol. 55:498-505, doi: 10.1007/s13580-014-0053-2.

Contreras, R.N. and K. Shearer. 2020. Exposing seeds of Galtonia candicans to ethyl methanesulphonate reduced inflorescence height, lodging, and fertility. HortScience 55:621-624, doi: 10.21273/HORTSCI14775-19.

Contreras, R.N. and M.W. Friddle. 2015. 'Oregon Snowflake' flowering currant. HortScience 50: 320-321, doi: 10.21273/HORTSCI.50.2.320.

Daskalov, S. 1986. Mutation breeding in pepper, INIS-XA-390. IAEA, Vienna.

Datta, S.K. 2012. Success story of induced mutagenesis for development of new ornamental varieties. Bioremediation Biodivers. Bioavailab. 6:15-26.

Datta, S.K. 2014. Induced mutagenesis: Basic knowledge for technological success, p. 97-140. In: N.B. Tomlekova, M.I. Kozgar, and M.R. Wani (eds.). Mutagenesis: Exploring genetic diversity of crops. Wageningen Academic Publishers, Wageningen, doi: 10.3920/ 978-90-8686-796-7_5.

Datta, S.K. and D. Chakrabarty. 2005. Classical mutation breeding and molecular methods for genetic improvement of ornamentals, $p$ 260-303. In: S.K. Datta (ed.). Role of classical mutation breeding in crop improvement. Daya Publishing House, Delhi.

Donà, M., L. Ventura, A. Macovei, M. Confalonieri, M. Savio, A. Giovannini, D. Carbonera and A. Balestrazzi. 2013. Gamma irradiation with different dose rates induces different DNA damage responses in Petunia $\times$ hybrida cells. J. Plant Physiol. 170:780-787, doi: 10.1016/j.jplph.2013.01.010.

Donini, B. 1967. Effects of chronic gamma-irradiation on Pinus pinea and Pinus halepensis. Radiat. Bot. 7:183-192, doi: 10.1016/S00337560(67)80018-8.

Doorenbos, J. and J.J. Karper. 1975. X-ray induced mutations in Begonia $\times$ hiemalis. Euphytica 24:13-19, doi: 10.1007/BF00147163.

Douglas, G.C. 1986. Effects of gamma radiation on morphogenesis and mutagenesis in cultured stem explants of poplar, p. 121-128. In: International Atomic Energy Agency (ed.). Nuclear techniques and in vitro culture for plant improvement. International Atomic Energy Agency, Vienna.

Dowrick, G.J. and A. El Bayoumi. 1966. The induction of mutations in chrysanthemum using Xand gamma radiation. Euphytica 15:204-210, doi: $10.1007 / \mathrm{BF} 00022325$.

Duron, M. 1992. Induced mutations through EMS treatment after adventitious bud formation on shoot internodes of Weigela cv. Bristol Ruby. Acta Hort. 320:113-118, doi: 10.17660/Acta Hortic.1992.320.15.

Elena, S.F., V.S. Cooper, and R.E. Lenski. 1996. Punctuated evolution caused by selection of rare beneficial mutations. Science 272:1802-1804, doi: $10.1126 /$ science. 272.5269 .1802 .

El-Lakany, M.H. and O. Sziklai. 1970. Effects of gamma-irradiation on some western conifers. Radiat. Bot. 10:411-420, doi: 10.1016/S00337560(70)80003-5

Fang, J. and S. Traore. 2011. In vitro mutation induction of Saintpaulia using ethyl methanesulfonate. HortScience 46:981-984, doi: 10.21273/ HORTSCI.46.7.981.

Gallone, A., A. Hunter, and G.C. Douglas. 2012 Radiosensitivity of Hebe 'Oratia Beauty' and
'Wiri Mist' irradiated in vitro with gamma rays from ${ }^{60}$ Co. Scientia Hort. 138:36-42, doi: 10.1016/j.scienta.2012.02.006.

Gates, R.R. 1930. Mutations induced by X-rays. Nature 126:40, doi: 10.1038/126040a0.

Gautam, A.S., K.C. Sood, and A.K. Richarria. 1992. Mutagenic effectiveness and efficiency of gamma-rays, ethyl methane sulphonate and their synergistic effects in black gram (Vigna mungo L.). Cytologia (Tokyo) 57:85-89, doi: 10.1508/cytologia.57.85.

Ghani, M. and S.K. Sharma. 2019. Induction of powdery mildew resistance in gerbera (Gerbera jamesonii) through gamma irradiation. Physiol. Mol. Biol. Plants 25:159-166, doi: 10.1007/ s12298-018-0613-5.

Ghani, M., S. Kumar, and M. Thakur. 2014. Physiological and biochemical responses of gerbera (Gerbera jamesonii Hook.) to physical and chemical mutagenesis. J. Hort. Sci. Biotechnol. 89:301-306, doi: 10.1080/14620316.2014.1151 3083.

Ghosh, S. and M. Ganga. 2019. Determination of lethal dose for ethyl methane sulphonate induced mutagenesis in jasmine. Chem. Sci. Rev. Lett. 8:6-10.

Ghosh, S., M. Ganga, and K. Soorianathasundaram. 2019. Studies of mutagenic effectiveness and efficiency of gamma rays and ethyl methane sulphonate in jasmine. Curr. J. Appl. Sci. Technol. 38:1-8, doi: 10.9734/cjast/2019/ v38i630414.

Gichner, T. and J. Velemínský. 1967. The mutagenic activity of 1-alkyl-1-nitrosoureas and 1-alkyl-3nitro-1-nitrosoguanidines. Mutat. Res. 4:207212, doi: 10.1016/0027-5107(67)90073-5.

Giovanni, A., V. Scariot, M. Caser, A. Buttafava, A. Mansuino, G.G. Ghione, M. Savona, M.E. Sabatini, D. Carbonera, and A. Balestrazzi. 2015. Mutation breeding using gamma rays to increase seed germination in Rosa hybrida Acta Hort. 1087:373-378, doi: 10.17660/ ActaHortic.2015.1087.49.

Girija, M. and D. Dhanavel. 2009. Mutagenic effectiveness and efficiency of gamma rays, ethyl methane sulphonate and their combined treatments in cowpea (Vigna unguiculata L. Walp). Glob. J. Mol. Sci. 4:68-75.

Gladstones, J.S. and C.M. Francis. 1965. Studies on the use of mutagenic agents in plant breeding. ii. The effects of dose and seed moisture content on mutation production in Lupinus angustifolius by X-rays. Austral. J. Agr. Res. 16:301-310, doi: 10.1071/AR9650301.

Gong, S., H. Fu, and J. Wang. 2010. ISSR Analysis of M1 generation of Gladiolus hybridus Hort treated by EMS. J. Northeast Agr. Univ. 17:22-26

Goyal, S. and S. Khan. 2010. Induced mutagenesis in urdbean (Vigna mungo L. Hepper): A review. Intl. J. Bot. 6:194-206, doi: 10.3923/ ijb.2010.194.206.

Greene, E.A., C.A. Codomo, N.E. Taylor, J.G. Henikoff, B.J. Till, S.H. Reynolds, L.C. Enns, C. Burtner, J.E. Johnson, A.R. Odden, L. Comai, and S. Henikoff. 2003. Spectrum of chemically induced mutations from a largescale reverse-genetic screen in Arabidopsis Genetics 164:731-740, doi: 10.1093/genetics/ 164.2.731.

Greer, S.P. and T.A. Rinehart. 2009. In vitro germination and dormancy responses of Hydrangea macrophylla and Hydrangea paniculata seeds to ethyl methane sulfonate and cold treatment. HortScience 44:764-769, doi: 10.21273/ HORTSCI.44.3.764.

Grunewalt, J. 1983. In vitro mutagenesis of Saintpaulia and Pelargonium cultivars. Acta Hort 
131:339-344, doi: 10.17660/ActaHortic.1983. 131.40 .

Gupta, M.N. and T. Matsuo. 1969. Effects of thermal neutrons and gamma rays on seeds of Antirrhinum majus and their modification by water content and oxygen concentration. Radioisotopes 18:52-55, doi: 10.3769/radioisotopes.18.2_52.

Hamatani, M., Y. Iitsuka, T. Abe, K. Miyoshi, M. Yamamoto, and S. Yoshida. 2001. Mutant flowers of dahlia (Dahlia pinnata Cav.) induced by heavy-ion beams. RIKEN Accelerator Prog. Rpt. 34:169-170.

Hara, Y., T. Abe, K. Sakamoto, Y. Miyazawa, and S. Yoshida. 2003. Effects of heavy-ion irradiation in rose (Rosa hybrida 'Bridal Fantasy') (II). RIKEN Accelerator Prog. Rpt. 36:135.

Hargrove, T.R. and V.L. Cabanilla. 1979. The impact of semidwarf varieties on Asian ricebreeding programs. Bioscience 29:731-735, doi: $10.2307 / 1307667$.

Hase, Y., M. Okamura, D. Takeshita, I. Narumi, and A. Tanaka. 2010. Efficient induction of flower-color mutants by ion beam irradiation in petunia seedlings treated with high sucrose concentration. Plant Biotechnol. 27:99-103, doi: 10.5511/plantbiotechnology.27.99.

Hayashi, Y., S. Ishii, T. Hirano, K. Ichinose, Y. Kazama, and T. Abe. 2019. New ornamental cherry cultivars induced by heavy-ion beam irradiation. Acta Hort. 1235:99-104, doi: 10.17660/ActaHortic.2019.1235.13.

Heffron, L., A. Blowers, and S. Korban. 2006. Chemical mutagenesis in snapdragon (Antirrhinum majus). HortScience 41:1021, doi: 10.21273/HORTSCI.41.4.1021A.

Hekstra, G. and C. Broertjes. 1968. Mutation breeding in bulbous Iris. Euphytica 17:345-351, doi: 10.1007/BF00056234.

Hirano, T., Y. Kazama, K. Ishii, S. Ohbu, Y. Shirakawa, and T. Abe. 2015. Comprehensive identification of mutations induced by heavyion beam irradiation in Arabidopsis thaliana. Plant J. 82:93-104, doi: 10.1111/tpj.12793.

Hisamura, A., D. Mine, T. Takeda, T. Abe, Y. Hayashi, and T. Hirano. 2016. Breeding of summer-autumn flowering Chrysanthemum cv. Hakuryo with a little generation of malformed flower. RIKEN Accelerator Prog. Rpt. 49:24.

Hohmann, U., G. Jacobs, and C. Jung. 2005. An EMS mutagenesis protocol for sugar beet and isolation of non-bolting mutants. Plant Breed. 124:317-321, doi: 10.1111/j.1439-0523.2005. 01126.x.

Horita, M., K. Sakamoto, T. Abe, and S. Yoshida. 2002. Induction of mutation in Sandersonia aurantiaca Hook. by heavy-ion beam irradiation. RIKEN Accelerator Prog. Rpt. 35:131.

Hoskins, T. and R.N. Contreras. 2019. Exposing seeds of Sarcococca confusa to increased concentrations and durations of ethyl methanesulphonate reduced seed germination, twinning, and plant size. HortScience 54:1902-1906, doi: 10.1111/j.1439-0523.2005.01126.x.

Hossain, Z., A.K.A. Mandal, S.K. Datta, and A.K. Biswas. 2006a. Isolation of a NaCl-tolerant mutant of Chrysanthemum morifolium by gamma radiation: In vitro mutagenesis and selection by salt stress. Funct. Plant Biol. 33:91-101, doi: 10.1071/FP05149.

Hossain, Z., A.K.A. Mandal, S.K. Datta, and A.K. Biswas. 2006b. Development of NaCl-tolerant strain in Chrysanthemum morifolium Ramat. through in vitro mutagenesis. Plant Biol. 8:450-461, doi: 10.1055/s-2006-923951.

Huxley, J. 1942. Evolution: The modern synthesis. Allen \& Unwin, London.

International Atomic Energy Agency. 2021. IAEA Mutant Variety Database. International Atomic
Energy Agency, Vienna. 20 June 2020. $<$ https://mvd.iaea.org/>

Iizuka, M., N. Kudo, Y. Kimura, Y. Hase, and A. Tanaka. 2001. Induction of mutation in Spiraea by ion beam irradiation; Effects of ion beams on germination of Spiraea seed, p. 45-46. In: M. Saidoh, A. Toraishi, H. Namba, H. Itoh, S. Tanaka, H. Naramoto, T. Sekine, A. Tanaka, Y. Kobayashi, K. Arakawa, M. Otsubo, S. Tajima, and S. Tanaka (eds.). TIARA Annual Report 2000, No. 2001-039. JAERI, Tōkai.

International Rice Research Institute. 1967. Annual Report for 1966. International Rice Research Institute, Manila.

Ishii, S., Y. Hayashi, H. Ryuto, N. Fukunishi, and T. Abe. 2009. A new cultivar 'Nishina Zaou' induced by heavy ion beam irradiation. RIKEN Accelerator Prog. Rpt. 42:11.

Ishizaka, H., E. Kondo, and N. Kameari. 2012. Production of novel flower color mutants from the fragrant cyclamen (Cyclamen persicum $\mathrm{x}$ C. purpurascens) by ion-beam irradiation. Plant Biotechnol. 29:201-208, doi: 10.5511/plantbio technology.12.0116a.

Jiang, P., Y. Chen, and H.D. Wilde. 2014. Optimization of EMS mutagenesis on petunia for TILLING. Adv. Crop Sci. Technol. 2:141, doi: 10.4172/2329-8863.1000141.

Kanaya, T., H. Saito, Y. Hayashi, N. Fukunishi, H. Ryuto, K. Miyazaki, T. Kusumi, T. Abe, and K. Suzuki. 2008. Heavy-ion beam-induced sterile mutants of verbena (Verbena $\times$ hybrida) with an improved flowering habit. Plant Biotechnol. 25:91-96, doi: 10.5511/plantbiotechnology.25.91.

Kang, E., Y. Lee, S.Y. Sung, B. Ha, S.H. Kim, D.S Kim, J. Kim, and S. Kang. 2013. Analysis of the genetic relationship of gamma-irradiated in vitro mutants derived from standard-type Chrysanthemum cv. Migok. Hort. Environ. Biotechnol. 54:76-81, doi: 10.1007/s13580-013-0124-9.

Kapadiya, D.B., S.L. Chawla, A.I. Patel, and D. Bhatt. 2016. Induction of variability through in vivo mutagenesis in chrysanthemum (Chrysanthemum morifolium Ramat.) var. Jaya. Indian J. Hort. 73:141-144, doi: 10.5958/ 0974-0112.2016.00035.9.

Kapadiya, D.B., S.L. Chawla, A.I. Patel, and T.R. Ahlawat. 2014. Exploitation of variability through mutagenesis in chrysanthemum (Chrysanthemum morifolium Ramat.) var. Maghi. Bioscan 9:1799-1804.

Kashikar, S.G. and A.S. Khalatkar. 1981. Breeding for flower colour in Petunia hybrida Hort. Acta Hort. 111:35-40, doi: 10.17660/ActaHortic. 1981.111.3.

Kaul, M.L.H. and A.K. Bhan. 1977. Mutagenic effectiveness and efficiency of EMS, DES and gamma-rays in rice. Theor. Appl. Genet. 50:241-246, doi: 10.1007/BF00273758.

Kazama, Y., H. Saito, Y.Y. Yamamoto, Y. Hayashi, H. Ichida, H. Ryuto, N. Fukunishi, and T. Abe. 2008. LET-dependent effects of heavy ion beam irradiation in Arabidopsis thaliana. Plant Biotechnol. 25:113-117, doi: 10.5511/ plantbiotechnology.25.113.

Kazama, Y., T. Hirano, H. Saito, Y. Liu, S. Ohbu, Y. Hayashi, and T. Abe. 2011. Characterization of highly efficient heavy-ion mutagenesis in Arabidopsis thaliana. BMC Plant Biol. 11:161, doi: 10.1186/1471-2229-11-161.

Khan, M.H. and S.D. Tyagi. 2013. A review on induced mutagenesis in soybean. J. Cereals Oilseed 4:19-25, doi: 10.5897/JCO10.004.

Khurshid, H., S.A. Jan, Z.K. Shinwari, M. Jamal, and S.H. Shah. 2018. An era of CRISPR/Cas9 mediated plant genome editing. Curr. Issues Mol. Biol. 26:47-54, doi: 10.21775/cimb.026. 047.
Kim, Y., K.S. Schumaker, and J. Zhu. 2006. EMS mutagenesis of Arabidopsis, p. 101-103. In: J. Salinas and J.J. Sanchez-Serrano (eds.). Arabidopsis protocols. 2nd ed. Humana Press, Totowa, NJ, doi: 10.1385/1-59745-003-0:101.

Kodym, A. and R. Afza. 2003. Physical and chemical mutagenesis, p. 189-203. In: E. Grotewold (ed.). Plant functional genomics: Methods and protocols. Humana Press, Totowa, NJ, doi: 10.1385/1-59259-413-1:189.

Kondo, E., M. Nakayama, N. Kameari, N. Tanikawa, Y. Morita, Y. Akita, Y. Hase, A. Tanaka, and H. Ishizaka. 2009. Red-purple flower due to delphinidin 3,5-diglucoside, a novel pigment for Cyclamen spp., generated by ion-beam irradiation. Plant Biotechnol. 26:565-569, doi: 10.5511/plantbiotechnology.26.565.

Koornneef, M., L.W.M. Dellaert, and J.H. van der Veen. 1982. EMS- and radiation-induced mutation frequencies at individual loci in Arabidopsis thaliana (L.). Heynh. Mutat. Res. 93:109-123, doi: 10.1016/0027-5107(82)90129-4.

Krumbiegel, G. 1979. Response of haploid and diploid protoplasts from Datura innoxia Mill. and Petunia hybrida $\mathrm{L}$. to treatment with X-rays and a chemical mutagen. Environ. Exp. Bot. 19:99-103, doi: 10.1016/0098-8472(79)90014-5.

Kudo, N., M. Iizuka, Y. Kimura, A. Tanaka, N. Shikazono, and H. Watanabe. 1998. Induction of mutation in strawberry and hydrangea by ion beam irradiation: Effects of ion beam irradiation on shoot regeneration of strawberry callus and germination of hydrangea seed, $\mathrm{p}$. 62-64. In: R. Tanaka, M. Saido, I. Nashiyama, H. Naramoto, T. Suwa, Y. Morita, A. Toraishi, H. Watanabe, M. Tani, S. Tajima, and S. Okada (eds.). TIARA annual report 1997, no. 98-016. JAERI, Tōkai.

Kukimura, H., F. Ikeda, H. Fujita, T. Maeta, K. Nakajima, K. Katagiri, K. Nakahira, and M. Somegou. 1976. Genetical, cytological and physiological studies on the induced mutants with special regard to effective methods for obtaining useful mutants in perennial woody plant, p. 93-137. In: International Atomic Energy Agency (ed.). Improvement of vegetatively propagated plants and tree crops through induced mutations. International Atomic Energy Agency, Vienna.

Kumari, K., K.K. Dhatt, and M. Kapoor. 2013. Induced mutagenesis in Chrysanthemum morifolium variety 'Otome Pink' through gamma irradiation. Bioscan 88:1489-1492.

Kurowska, M., A. Daszkowska-Golec, D. Gruszka, M. Marzec, M. Szurman, I. Szarejko, and M. Maluszynski. 2011. TILLING - a shortcut in functional genomics. J. Appl. Genet. 52:371390, doi: 10.1007/s13353-011-0061-1.

Laneri, U., R. Franconi, and P. Altavista. 1990. Somatic mutagenesis of Gerbera jamesonii Hybr.: Irradiation and in vitro culture. Acta Hort 280:395-402, doi: 10.17660/ActaHortic.1990. 280.64 .

Latado, R.R., A.H. Adames, and A.T. Neto. 2004. In vitro mutation of chrysanthemum (Dendranthema grandiflora Tzvelev) with ethylmethanesulphonate (EMS) in immature floral pedicels. Plant Cell Tissue Organ Cult. 77:103-106, doi: 10.1023/B:TICU.0000016481.18358.55.

Lee, J., Y. Chung, Y. Joung, T. Han, S. Kang, Y. Yoo, and G. Lee. 2010. Induction of mutations for stem quality in chrysanthemum (Dendranthema grandiflora) by using gamma-ray irradiation. Acta Hort. 855:177-182, doi: 10.17660/ ActaHortic.2010.855.25

Li, J., J. Yang, Y. Li, and L. Ma. 2020. Current strategies and advances in wheat biology. Crop J. 8:879-891, doi: 10.1016/j.cj.2020.03.004 
Li, X., Y. Song, K. Century, S. Straight, P. Ronald, X. Dong, M. Lassner, and Y. Zhang. 2001. A fast neutron deletion mutagenesis-based reverse genetics system for plants. Plant J. 27:235-242, doi: 10.1046/j.1365-313x.2001.01084.x.

Love, J.E. and M.J. Constantin. 1966. The induction of bud sports in Coleus blumei by fast neutrons. Proc. Amer. Soc. Hort. Sci. 88:627-630.

Loveless, A. 1958. Increased rate of plaque-type and host-range mutation following treatment of bacteriophage in vitro with ethyl methane sulphonate. Nature 181:1212-1213, doi: 10.1038/1811212a0.

Magori, S., A. Tanaka, and M. Kawaguchi. 2010. Physically induced mutation: Ion beam mutagenesis, p. 3-16. In: K. Meksen and G. Kahl (eds.). The handbook of plant mutation screening: Mining of natural and induced alleles. Wiley-Blackwell, Chichester, doi: 10.1002/ 9783527629398.ch1.

Maple, J. and S.G. Møller. 2007. Mutagenesis in Arabidopsis, p. 197-206. In: E. Rosato (ed.). Circadian rhythms: Methods in molecular biology. Volume 362. Humana Press, Totowa, NJ, doi: 10.1007/978-1-59745-257-1_14.

Marcotrigiano, M. 1997. Chimeras and variegation: Patterns of deceit. HortScience 32:773-784, doi: 10.21273/HORTSCI.32.5.773.

Matsumura, A., T. Nomizu, N. Furutani, K. Hayashi, Y. Minamiyama, and Y. Hase. 2010. Ray florets color and shape mutants induced by ${ }^{12} \mathrm{C}^{5+}$ ion beam irradiation in chrysanthemum. Scientia Hort. 123:558-561, doi: 10.1016/j. scienta.2009.11.004.

McCallum, C.M., L. Comai, E.A. Greene, and S. Henikoff. 2000. Targeting induced local lesions in genomes (TILLING) for plant functional genomics. Plant Physiol. 123:439-442, doi: 10.1104/pp.123.2.439.

Men, A.E., T.S. Laniya, I.R. Searle, I. IturbeOrmaetxe, I. Gresshoff, Q. Jiang, B.J. Carroll, and P.M. Gresshoff. 2002. Fast neutron mutagenesis of soybean (Glycine soja L.) produces a supernodulating mutant containing a large deletion in linkage group $\mathrm{H}$. Genome Lett. 3:147-155, doi: 10.1166/gl.2002.017.

Miyake, K. and Y. Imai. 1926. On a monstrous flower and its linkage in the japanese morning glory. J. Genet. 16:63-76, doi: 10.1007/ BF02983988.

Miyazaki, K., K. Suzuki, K. Iwaki, T. Kusumi, T. Abe, S. Yoshida, and H. Fukui. 2006. Flower pigment mutations induced by heavy ion beam irradiation in an interspecific hybrid of Torenia. Plant Biotechnol. 23:163-167, doi: 10.5511/ plantbiotechnology.23.163.

Miyazaki, K., K. Suzuki, T. Abe, Y. Katsumoto, S. Yoshida, and T. Kusumi. 2002. Isolation of variegated mutants of Petunia hybrida using heavy-ion beam irradiation. RIKEN Accelerator Prog. Rpt. 35:130.

Montesano, R., H. Brésil, and G.P. Margison. 1979. Increased excision of $\mathrm{O}^{6}$-methylguanine from rat liver DNA after chronic administration of dimethylnitrosamine. Cancer Res. 39:1798-1802.

Moore, C.N. and C.P. Haskins. 1935. X-ray induced modifications of flower color in the petunia. J. Hered. 26:349-355, doi: 10.1093/ oxfordjournals.jhered.a104121.

Morita, R., M. Kusaba, S. Iida, H. Yamaguchi, T. Nishio, and M. Nishimura. 2009. Molecular characterization of mutations induced by gamma irradiation in rice. Genes Genet. Syst. 84:361-370, doi: 10.1266/ggs.84.361.

Muller, H.J. 1927. Artificial transmutation of the gene. Science 66:84-87, doi: 10.1126/science. 66.1699 .84 .
Nagatomi, S. 1993. Enlargement of induced variations by combined method of chronic irradiations with callus culture in sugarcane. Gamma Field Symp. 30:87-110.

Nagatomi, S., E. Miyahira and K. Degi. 2000. Induction of flower mutation comparing with chronic and acute gamma irradiation using tissue culture techniques in Chrysanthemum morifolium Ramat. Acta Hort. 508:69-74, doi: 10.17660/ActaHortic.2000.508.8.

Nagatomi, S. and K. Degi. 2009. Mutation breeding of Chrysanthemum by gamma field irradiation and in vitro culture, p. 258-261. In: Q.Y. Shu (ed.). Induced plant mutations in the genomic era. Food and Agriculture Organization of the United Nations, Rome.

Nakano, M., J. Amano, Y. Watanabe, T. Nomizu, M. Suzuki, K. Mizunashi, S. Mori, S. Kuwayama, D. Han, H. Saito, H. Ryuto, N. Fukunishi, and T. Abe. 2010. Morphological variation in Tricyrtis hirta plants regenerated from heavy ion beam-irradiated embryogenic calluses. Plant Biotechnol. 27:155-160, doi: 10.5511/plantbiotechnology.27.155.

Napoli, C.A. and J. Ruehle. 1996. New mutations affecting meristem growth and potential in Petunia hybrida Vilm. J. Hered. 87:371-377, doi: 10.1093/oxfordjournals.jhered.a023016.

Navabi, Y., M. Norouzi, M. Arab, and S.D. Daylami. 2016. Mutagenesis via exposure to gamma-rays in tuberose (Polianthes tuberosa). Electronic J. Biol. 12:168-172.

Nishiguchi, M., T. Nanjo, and K. Yoshida. 2012. The effects of gamma irradiation on growth and expression of genes encoding DNA repairrelated proteins in lombardy poplar (Populus nigra var. italica). J. Environ. Radioact. 109:19-28, doi: 10.1016/j.jenvrad.2011.12.024.

Oates, K.M., D.H. Touchell, and T.G. Ranney. 2013. Induced variation in tetraploid Rudbeckia subtomentosa 'Henry Eilers' regenerated from gamma-irradiated callus. HortScience 48:831834, doi: 10.21273/HORTSCI.48.7.831.

Ogawa, D., T. Fujioka, T. Hirano, and T. Abe 2014. Effect of C-ion beam irradiation on survival rates and flower color mutations in statice (Limonium sinuatum Mill.). RIKEN Accelerator Prog. Rpt. 47:295.

Okamura, M., M. Nakayama, N. Umemoto, E.A. Cano, Y. Hase, Y. Nishizaki, N. Sasaki, and Y. Ozeki. 2013. Crossbreeding of a metallic color carnation and diversification of the peculiar coloration by ion-beam irradiation. Euphytica 191:45-56, doi: 10.1007/s10681-012-0859-x.

Okamura, M., N. Yasuno, M. Ohtsuka, A. Tanaka, N. Shikazono, and Y. Hase. 2003. Wide variety of flower-color and -shape mutants regenerated from leaf cultures irradiated with ion beams. Nucl. Instrum. Methods Phys. Res. B 206:574 578, doi: 10.1016/s0168-583x(03)00835-8.

Okamura, M., Y. Hase, Y. Furusawa, and A. Tanaka. 2015. Tissue-dependent somaclonal mutation frequencies and spectra enhanced by ion beam irradiation in chrysanthemum. Euphytica 202:333-343, doi: 10.1007/s10681-0141220-3.

Oladosu, Y., M.Y. Rarfii, N. Abdullah, G. Hussin, A. Ramli, H.A. Rahim, G. Miah, and M. Usman. 2016. Principle and application of plant mutagenesis in crop improvement: A review. Biotechnol. Biotechnol. Equip. 30:1-16, doi: 10.1080/13102818.2015.1087333.

Ossowski, S., K. Schneeberger, J.I. Lucas-Lledo, N. Warthmann, R.M. Clark, R.G. Shaw, D. Weigel, and M. Lynch. 2010. The rate and molecular spectrum of spontaneous mutations in Arabidopsis thaliana. Science 327:92-94, doi: 10.1126/science.1180677.
Padmadevi, K. and M. Jawaharlal. 2011. Induction of in vitro mutation in chrysantemum (Dendranthema grandiflora Tzvelev) ray florets (var. Ravi Kiran) using gamma rays and EMS. Floric. Ornam. Biotechnol. 5:74-77.

Pallavi, B., S.K. Nivas, L. D'Souza, T.R. Ganapathi, and S. Hegde. 2017. Gamma rays induced variations in seed germination, growth and phenotypic characteristics of Zinnia elegans var. Dreamland. Adv. Hort. Sci. 31:267-273, doi: 10.13128/ahs-20289.

Paramesh, T.H. and S. Chowdhury. 2005. Impact of explants and gamma irradiation dosage on in vitro mutagenesis in carnation (Dianthus caryophyllus L.). J. Appl. Hort. 7:43-45, doi: 10.37855/jah.2005.v07i01.11.

Peck, J.R. 1994. A ruby in the rubbish: Beneficial mutations, deleterious mutations and the evolution of sex. Genetics 137:597-606, doi: 10.1093/genetics/137.2.597.

Peng, S., J. Huang, K.G. Cassman, R.C. Laza, R.M. Visperas, and G.S. Khush. 2010. The importance of maintenance breeding: A case study of the first miracle rice variety IR8. Field Crops Res. 119:342-347, doi: 10.1016/j. fcr.2010.08.003.

Predieri, S. and N. Di Virgilio. 2007. In vitro mutagenesis and mutant multiplication, $\mathrm{p}$. 323-333. In: S.M. Jain and H. Häggman (eds.). Protocols for micropropagation of woody trees and fruits. Springer, Dordrecht, doi: 10.1007/ 978-1-4020-6352-7_30.

Preil, W., M. Engelhardt, and F. Walther. 1983. Breeding of low temperature tolerant poinsettia (Euphorbia pulcherrima) and chrysanthemum by means of mutation induction in in vitro culture. Acta Hort. 131:345-355, doi: 10.17660/ ActaHortic. 1983.131.41.

Puchooa, D. 2005. In vitro mutation breeding of Anthurium by gamma radiation. Intl. J. Agr. Biol. 7:11-20.

Raghuvanshi, S.S. and A.K. Singh. 1979. Gammaray induced mutations in diploid and autotetraploid perennial Portulaca grandiflora Hook. Indian J. Hort. 36:84-87.

Rapoport, J.A. 1946. Carbonyl compounds and the chemical mechanism of mutation. Proc. U.S.S.R. Acad. Sci. (Atmos. Ocean. Phys.) 54:65-67.

Reyes-Borja, W.O., I. Sotomayor, I. Garzón, D. Vera, M. Cedeño, B. Castillo, A. Tanaka, Y. Hase, Y. Sekozawa, S. Sugaya, and $\mathrm{H}$. Gemma. 2007. Alteration of resistance to black sigatoka (Mycosphaerella fijiensis Morelet) in banana by in vitro irradiation using carbon ionbeam. Plant Biotechnol. 24:349-353, doi: 10.5511/plantbiotechnology.24.349.

Richter, A. and W.R. Singleton. 1955. The effect of chronic gamma radiation on the production of somatic mutations in carnations. Proc. Natl. Acad. Sci. USA 41:295-300, doi: 10.1073/ pnas.41.5.295.

Rinehart, T.A., P.A. Wadl, and M.E. Staton. 2018. An update on Hydrangea macrophylla breeding targets and genomics. Acta Hort. 1191:217-224, doi: 10.17660/ActaHortic.2018.1191.30.

Roebbelen, G. 1990. Mutation breeding for quality improvement a case study for oilseed crops, INIS-mf-13553. IAEA, Vienna.

Roest, S., M.A.E. van Berkel, G.S. Bokelmann, and C. Broertjes. 1981. The use of an in vitro adventitious bud technique for mutation breeding of Begonia $\times$ hiëmalis. Euphytica 30:381388, doi: $10.1007 / \mathrm{BF} 00034000$.

Roychowdhury, R. and J. Tah. 2011. Assessment of chemical mutagenic effects in mutation breeding programme for $\mathrm{M}_{1}$ generation of carnation (Dianthus caryophyllus). Res. Plant Biol. 1:23-32. 
Ryuto, H., N. Fukunishi, Y. Hayashi, H. Ichida, T. Abe, M. Kase, and Y. Yano. 2008. Heavy-ion beam irradiation facility for biological samples in RIKEN. Plant Biotechnol. 25:119-122, doi: 10.5511/plantbiotechnology.25.119.

Sagawa, Y. and G.A.L. Mehlquist. 1959. Some Xray induced mutants in the carnation: Dianthus caryophyllus. J. Hered. 50:78-80, doi: 10.1093/ oxfordjournals.jhered.a106881.

Sakamoto, K., Y. Takatori, R. Chiwata, T. Matsumura, K. Tsukiashi, Y. Hayashi, and T. Abe. 2016. Production of mutant line with early flowering at a low temperature in spray-type chrysanthemum cultivar induced by $\mathrm{C}$-ion Beam irradiation. RIKEN Accelerator Prog. Rpt. 49:262.

Sasaki, K., R. Aida, T. Niki, H. Yamaguchi, T. Narumi, T. Nishijima, Y. Hayashi, H. Ryuto, N. Fukunishi, T. Abe, and N. Ohtsubo. 2008. Highefficiency improvement of transgenic Torenia flowers by ion beam irradiation. Plant Biotechnol. 25:81-89, doi: 10.5511/plantbiotechnology. 25.81 .

Sathyanarayana, E., G. Sharma, T. Tirkey, B.K. Das, K. Divya, and J. Kumar. 2019. Studies of gamma irradiation on vegetative and floral characters of gladiolus (Gladiolus grandiflorus L.). J. Pharmacognosy Phytochem. 8:227-230.

Schendel, P.F. and I. Michaeli. 1984. A model for the mechanism of alkylation mutagenesis. Mutat. Res. 125:1-14, doi: 10.1016/0027-5107 (84)90026-5.

Schultz, S.T. and M. Lynch. 1997. Mutation and extinction: The role of variable mutational effects, synergistic epistasis, beneficial mutations, and degree of outcrossing. Evolution 51:1363-1371, doi: 10.1111/j.1558-5646.1997. tb01459.x.

Schultz, S.T., M. Lynch, and J.H. Willis. 1999. Spontaneous deleterious mutation in Arabidopsis thaliana. Proc. Natl. Acad. Sci. USA 96:1139311398, doi: 10.1073/pnas.96.20.11393.

Schum, A. 2003. Mutation breeding in ornamentals: An efficient breeding method? Acta Hort. 621:47-60, doi: 10.17660/ActaHortic.2003.612.6.

Sekiguchi, F., K. Yamakawa, and H. Yamaguchi. 1971. Radiation damage in shoot apical meristems of Antirrhinum majus and somatic mutations in regenerated buds. Radiat. Bot. 11: 157-169, doi: 10.1016/S0033-7560(71)90693-4.

Senapati, S.K. and G.R. Rout. 2008. In vitro mutagenesis of rose with ethylmethanesulphonate (EMS) and early selection using RAPD Markers. Adv. Hort. Sci. 22:218-222.

Shikazono, N., C. Suzuki, S. Kitamura, H. Watanabe, S. Tano, and A. Tanaka. 2005. Analysis of mutations induced by carbon ions in Arabidopsis thaliana. J. Expt. Bot. 56:587-596, doi: 10.1093/jxb/eri047.

Shukla, A., S. Kashyap, V. Ramteke, L. Sinha, and M. Netam. 2018. Effect of gamma rays on flowering and vase life of gladiolus (Gladiolus grandiflorus L.). J. Pharmacognosy Phytochem. 7:558-561.

Shukla, V.K., Y. Doyon, J.C. Miller, R.C. DeKelver, E.A. Moehle, S.E. Worden, J.C. Mitchell, N.L. Arnold, S. Gopalan, X. Meng, V.M. Choi, J.M. Rock, Y.Y. Wu, G.E. Katibah, G. Zhifang, D. McCaskill, M.A. Simpson, B. Blakeslee, S.A. Greenwalt, H.J. Butler, S.J. Hinkley, L. Zhang, E.J. Rebar, P.D. Gregory, and F.D. Urnov. 2009. Precise genome modification in the crop species Zea mays using zinc-finger nucleases. Nature 459:437-441, doi: 10.1038/ nature07992.

Simard, M., N. Michaux-Ferriere, and A. Silvy. 1992. Variants of carnation (Dianthus caryophyllus L.) obtained by organogenesis from irradiated petals. Plant Cell Tissue Organ Cult. 29:37-42, doi: 10.1007/BF00036144.

Singh, P.K., R. Sadhukhan, K. Roy, and H.K. Sarkar. 2013. Effect of EMS on morpho-anatomical changes in tuberose (Polianthes tuberosa L.). Floric. Ornam. Biotechnol. 7:103-105.

Singh, V.N., B.K. Banerji, A.K. Dwivedi, and A.K. Verma. 2009. Effect of gamma irradiation on African marigold (Tagetes erecta L.) cv. Pusa Narangi Gainda. J. Hort. Sci. 4:36-40.

Sink, K.C., Jr. 1973. The inheritance of apetalous flower type in Petunia hybrida Vilm. and linkage tests with the genes for flower doubleness and grandiflora character and its use in hybrid seed production. Euphytica 22:520-526, doi: 10.1007/BF00036650.

Smilansky, Z., N. Umiel, and N. Zieslin. 1986. Mutagenesis in roses (cv. Mercedes). Environ. Exp. Bot. 26:279-283, doi: 10.1016/0098-8472 (86) $90040-7$

Smith, A.G. and A.K. Noyszewski. 2018. Mutagenesis breeding for seedless varieties of popular landscape plants. Acta Hort. 1191:43-52, doi: 10.17660/ActaHortic.2018.1191.7.

Smith, W.A. and M.H. Brand. 2012. 'Summer Skies' Buddleja davidii. HortScience 47:126127, doi: 10.21273/HORTSCI.47.1.126.

Sniegowski, P.D. and P.J. Gerrish. 2010. Beneficial mutations and the dynamics of adaptation in asexual populations. Philosophical Transactions Royal Soc. B 365:1255-1263, doi: 10.1098/ rstb.2009.0290

Sparrow, A.H., A.F. Rogers, and S.S. Schwemmer. 1968. Radiosensitivity studies with woody plants -I acute gamma irradiation survival data for 28 species and predictions for 190 species. Radiat. Bot. 8:149-174, doi: 10.1016/ S0033-7560(68)80071-7.

Spielmeyer, W., M.H. Ellis, and P.M. Chandler. 2002. Semidwarf (sd-1), 'Green Revolution' rice, contains defective gibberellin 20-oxidase gene. Proc. Natl. Acad. Sci. USA 99:90439048, doi: 10.1073/pnas.132266399.

Stadler, L.J. 1928a. Mutations in barley induced by X-rays and radium. Science 68:186-187, doi: 10.1126/science.68.1756.186.

Stadler, L.J. 1928b. Genetic effects of X-rays in maize. Proc. Natl. Acad. Sci. USA 14:69-75, doi: 10.1073/pnas.14.1.69.

Sugiyama, M., H. Saito, H. Ichida, Y. Hayashi, H. Ryuto, N. Fukunishi, T. Terakawa, and T. Abe. 2008a. Biological effects of heavy-ion beam irradiation on cyclamen. Plant Biotechnol. 25:101104, doi: 10.5511/plantbiotechnology.25.101.

Sugiyama, M., Y. Hayashi, N. Fukunishi, H. Ryuto, T. Terakawa, and T. Abe. 2008b. Development of flower colour mutant of Dianthus chinensis var. Semperflorens by heavy-ion beam irradiation. RIKEN Accelerator Prog. Rpt. 41:229.

Sundar, P., K. Ajit, C. Preeti, S. Ranjan, and T. Shailesh. 2017. Determination of lethal dose for gamma rays induced mutagenesis in different cultivars of dahlia. J. Hill Agr. 8:279-282, doi: 10.5958/2230-7338.2017.00055.6.

Suzuki, K., Y. Takatsu, T. Gonai, M. Nogi, K. Sakamoto, N. Fukunishi, H. Ryuto, H. Saito, T. Abe, S. Yoshida, and M. Kasumi. 2005. Flower color mutation in spray-type chrysanthemum (Dendranthema grandiflorum (Ramat.) Kitamura) induced by heavy-ion beam irradiation. RIKEN Accel. Prog. Rpt. 38:138.

Swaroop, K., R. Jain, and T. Janakiram. 2015. Effect of different doses of gamma rays for induction of mutation in Bougainvillea cv Mahatma Gandhi. Indian J. Agr. Sci. 85:1245-1247.

Swarup, V. and S.P.S. Raghava. 1974. Induced mutation for resistance to leaf-curl virus and its inheritance in garden zinnia. Indian J. Genet. Plant Breed. 34:17-21.

Taheri, S., T.L. Abdullah, S.M. Jain, M. Sahebi, and P. Azizi. 2017. TILLING, high-resolution melting (HRM), and next-generation sequencing (NGS) techniques in plant mutation breeding. Mol. Breed. 37:40, doi: 10.1007/s11032-0170643-7.

Takahashi, M., S. Kohama, K. Kondo, M. Hakata, Y. Hase, N. Shikazono, A. Takana, and H. Morikawa. 2005. Effects of ion beam irradiation on the regeneration and morphology of Ficus thunbergii Maxim. Plant Biotechnol. 22:63-67, doi: 10.5511/plantbiotechnology.22.63.

Talebi, A.B., A.B. Talebi, and B. Shahrokhifar. 2012. Ethyl methane sulphonate (EMS) induced mutagenesis in malaysian rice (cv. MR219) for lethal dose determination. Amer. J. Plant Sci. 3:1661-1665, doi: 10.4236/ajps.2012.312202.

Tanaka, A., N. Shikazono, and Y. Hase. 2010. Studies on biological effects of ion beams on lethality, molecular nature of mutation, mutation rate, and spectrum of mutation phenotype for mutation breeding in higher plants. J. Radiat. Res. (Tokyo) 51:223-233, doi: 10.1269/jrr.09143.

Tanokashira, Y., M. Tamari, S. Nagayoshi, Y. Hayashi, T. Hirano, and T. Abe. 2016. Induction of flower color mutants by heavy-ion irradiation to leaf blades of spray-mum 'Southern Chelsea'. RIKEN Accelerator Prog. Rpt. 49:261.

Tanokashira, Y., S. Nagayoshi, T. Hirano, and T. Abe. 2014. Effects of heavy-ion-beam irradiation on flower-color mutation in chrysanthemum. RIKEN Accelerator Prog. Rpt. 47:297.

Tirkey, P. and D. Singh. 2019. Effect of induced mutagenesis on different characters of gladiolus (Gladiolus grandifloras L.). J. Pharmacognosy Phytochem. 8:650-654.

Tiwari, A.K. and V. Kumar. 2011. Gamma-rays induced morphological changes in pot marigold (Calendula officinalis). Progress. Agr. 11: 99-102.

Tiwari, A.K., R.M. Srivastava, V. Kumar, L.B. Yadav, and S.K. Misra. 2010. Gamma-rays induced morphological changes in gladiolus. Progress. Agr. 10:75-82.

Van Harten, A.M. 1998. Mutation breeding: Theory and practical applications. Cambridge University Press, Cambridge.

Van Tuyl, J.M. and K. Lim. 2003. Interspecific hybridisation and polyploidisation as tools in ornamental plant breeding. Acta Hort. 612: 13-22, doi: 10.17660/ActaHortic.2003.612.1.

Venkatachalam, P. and N. Jayabalan. 1997. Effect of gamma rays on some qualitative and quantitative characters in Zinnia elegans Jacq. Indian J. Genet. Plant Breed. 57:255-261.

Vining, K.J., R.N. Contreras, M. Ranik, and S.H Strauss. 2012. Genetic methods for mitigating invasiveness of woody ornamental plants: Research needs and opportunities. HortScience 47:1210-1216, doi: 10.21273/HORTSCI.47. 9.1210 .

Wakita, N., Y. Kazama, Y. Hayashi, H. Ryuto, N. Fukunishi, K. Yamamoto, S. Ijichi, and T. Abe. 2008. Induction of flower-color mutation by $\mathrm{C}$-ion irradiation in spray-type chrysanthemum. RIKEN Accelerator Prog. Rpt. 41:230.

Walther, F. and A. Sauer. 1986a. Analysis of radiosensitivity: A basic requirement for in vitro somatic mutagenesis II. Gerbera jamesonii, p. 155-159. In: International Atomic Energy Agency (ed.). Nuclear techniques and in vitro culture for plant improvement. International Atomic Energy Agency, Vienna.

Walther, F. and A. Sauer. 1986b. In vitro mutagenesis in roses. Acta Hort. 189:37-46, doi: 10.17660/ActaHortic.1986.189.4. 
Walther, F. and A. Sauer. 1990. Influence of acute and fractioned X-ray doses on shoot production of in vitro derived explants of Gerbera jamesonii H. Bolus. Plant Breed. 105:137-143, doi: 10.1111/j.1439-0523.1990.tb00466.x.

Wang, A.S., D.S.K. Cheng, J.B. Milcic, and T.C. Yang. 1988. Effect of X-ray irradiation on maize inbred line B73 tissue cultures and regenerated plants. Crop Sci. 28:358-362, doi: 10.2135/ cropsci1988.0011183X002800020037x.

Wang, J., J. Sui, Y. Xie, H. Guo, L. Qiao, L. Zhao, S. Yu, and L. Liu. 2015. Generation of peanut mutants by fast neutron irradiation combined with in vitro culture. J. Radiat. Res. (Tokyo) 56:437-445, doi: 10.1093/jrr/rru121.

Wang, P., Y. Zhang, L. Zhao, B. Mo, and T. Luo. 2017. Effect of gamma rays on Sophora davidii and detection of DNA polymorphism through ISSR marker. BioMed Res. Int. 2017: doi: 10.1155/2017/8576404.

Wani, A.A. 2009. Mutagenic effectiveness and efficiency of gamma rays, ethyl methane sulphonate and their combination treatments in chickpea (Cicer arietinum L.). Asian J. Plant Sci. 8:318-321, doi: 10.3923/ajps.2009.318.321.

Wani, M.R., M.I. Kozgar, S. Khan, M.A. Ahanger, and P. Ahmad. 2013. Induced mutagenesis for the improvement of pulse crops with special reference to mung bean: A review update, $\mathrm{p}$. 247-288. In: P. Ahmad, M.R. Wani, M.M Azooz, and L.P. Tran. (eds.). Improvement of crops in the era of climatic changes. Volume 1.
Springer, New York, NY, doi: 10.1007/ 978-1-4614-8830-9_11.

Webb, K.J., M. Robbins, T.L. Wang, M. Parniske, and A. Márquez. 2005. Mutagenesis, p. 177-186. In: J. Márquez (ed.). Lotus japonicus handbook. Springer, Dordrecht, doi: 10.1007/ 1-4020-3735-X_18.

Weigle, J.L. and J.K. Butler. 1983. Induced dwarf mutant in Impatiens platypetala. J. Hered. 74:200, doi: 10.1093/oxfordjournals.jhered.a109764.

Wilde, H.D., Y. Chen, P. Jiang, and A. Bhattacharya. 2012. Targeted mutation breeding of horticultural plants. Emir. J. Food Agr. 24:31-41, doi: 10.9755/ejfa.v24i1.10596.

Wolfe, K.H., W. Li, and P.M. Sharp. 1987. Rates of nucleotide substitution vary greatly among plant mitochondrial, chloroplast, and nuclear DNAs. Proc. Natl. Acad. Sci. USA 84:9054-9058, doi: 10.1073/pnas.84.24.9054.

Wongpiyasatid, A. and P. Hormchan. 2000. New mutants of perennial Portulaca grandiflora through gamma radiation. Agr. Nat. Resour. 34:408-416.

Wongpiyasatid, A., T. Thinnok, T. Taychasinpitak, P. Jompuk, K. Chusreeaeom, and S. Lamseejan. 2007. Effects of acute gamma irradiation on adventitious plantlet regeneration and mutation from leaf cuttings of african violet (Saintpaulia ionantha). Agr. Nat. Resour. 41:633-640.

Yamaguchi, H., S. Nagatomi, T. Morishita, K. Degi, A. Tanaka, N. Shikazono, and Y. Hase. 2003. Mutation induced with ion beam irradiation in rose. Nucl. Instrum. Methods Phys. Res. B 206:561-564, doi: 10.1016/ S0168-583X(03)00825-5.

Yamaguchi, H., Y. Hase, A. Tanaka, N. Shikazono, K. Degi, A. Shimizu, and T. Morishita. 2009. Mutagenic effects of ion beam irradiation on rice. Breed. Sci. 59:169-177, doi: 10.1270/ jsbbs.59.169.

Yu, L., W. Li, Y. Du, G. Chen, S. Luo, R. Liu, H. Feng, and L. Zhou. 2016. Flower color mutants induced by carbon ion beam irradiation of geranium (Pelargonium $\times$ hortorum, Bailey). Nucl. Sci. Tech. 27:112, doi: 10.1007/s41365-0160117-3.

Zalewska, M., A. Tymoszuk, and N. Miler. 2011. New chrysanthemum cultivars as a result of in vitro mutagenesis with the application of different explant types. Acta Sci. Pol. Hortorum Cultus 10:109-123.

Zhang, Y., F. Zhang, X. Li, J.A. Baller, Y. Qi, C.G. Starker, A.J. Bogdanove, and D.F. Voytas. 2013. Transcription activator-like effector nucleases enable efficient plant genome engineering. Plant Physiol. 161:20-27, doi: 10.1104/pp.112.205179.

Zhou, L.B., W.J. Li, S. Ma, X.C. Dong, L.X. Yu, Q. Li, G.M. Zhou, and Q.X. Gao. 2006. Effects of ion beam irradiation on adventitious shoot regeneration from in vitro leaf explants of Saintpaulia ionahta. Nucl. Instrum. Methods Phys. Res. B 244:349-353, doi: 10.1016/j. nimb.2005.10.034 